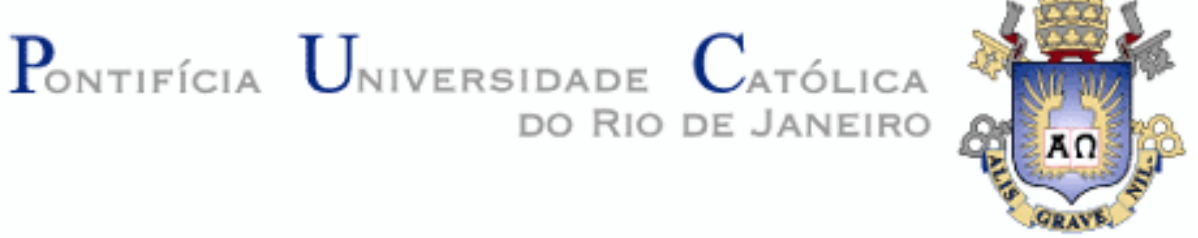

Leandro Schoemer Jardim rotinas de programação da produção

Dissertação de Mestrado

Dissertação apresentada como requisito parcial para obtenção do grau de Mestre pelo Programa de Pósgraduação em Administração de Empresas do Departamento de Administração da PUC-Rio.

Orientadora: Prof. Sandra Regina da Rocha-Pinto

Rio de Janeiro

Março de 2017 


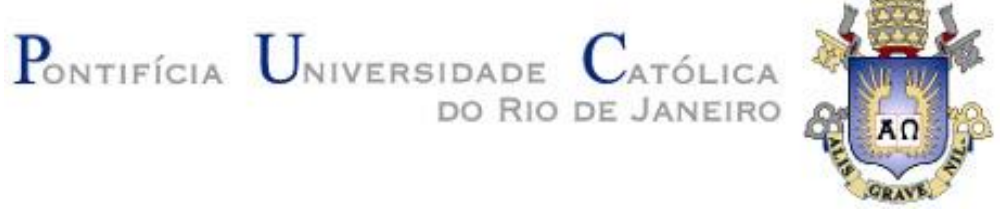

Leandro Schoemer Jardim

\section{A compreensão das competências nas rotinas de programação da produção}

Dissertação apresentada como requisito parcial para obtenção do grau de Mestre pelo Programa de PósGraduação em Administração de Empresas do Departamento de Administração da PUC-Rio. Aprovada pela Comissão Examinadora abaixo assinada.

Profa. Sandra Regina da Rocha Pinto
Orientadora
Departamento de Administração - PUC-Rio

Profa. Andrea Cherman

Departamento de Administração - PUC-Rio

Prof. Ricardo Sarmento Costa

Trilha Desenvolvimento de Projetos

Prof ". Mônica Herz

Vice-Decana de Pós-Graduação do CCS - PUC-Rio

Rio de Janeiro, 27 de março de 2017 
Todos os direitos reservados. É proibida a reprodução total ou parcial do trabalho sem autorização da universidade, do autor e do orientador.

\section{Leandro Schoemer Jardim}

Bacharel em Comunicação Social pela PUC-Rio, com habilitações em Publicidade e Jornalismo (2002). Especialista em Engenharia de Produção pelo Instituto Nacional de Tecnologia - INT (2004) e pela Sociedade Educacional de Santa Catarina - SOCIESC (2013). Professor convidado em MBAs da Fundação Getúlio Vargas (FGV), da Sociedade Educacional de Santa Catarina (SOCIESC) e da Fundação Centro de Análise, Pesquisa e Inovação Tecnológica (FUCAPI/AM) nas disciplinas "Tecnologias de Programação, Acionamento e Controle de Operações" e "Projeto Integrado de Gestão" (Orientação de TCC). Possui 12 anos de experiência em consultoria na área de planejamento da produção.

Ficha Catalográfica

Jardim, Leandro Schoemer

A compreensão das competências nas rotinas de programação da produção / Leandro Schoemer Jardim ; orientadora: Sandra Regina da Rocha-Pinto. - 2017.

97 f. : il. ; $30 \mathrm{~cm}$

Dissertação (mestrado)-Pontifícia Universidade Católica do Rio de Janeiro, Departamento de Administração, 2017.

Inclui bibliografia

1. Administração - Teses. 2. Rotinas organizacionais. 3. Competências. 4. Programação da produção. 5. Gestão de operações. I. Rocha-Pinto, Sandra Regina da. II. Pontifícia Universidade Católica do Rio de Janeiro. Departamento de Administração. III. Título. 
Para meu filho, João, pela força advinda do amor. Para minha esposa, Marina, pela parceria e apoio irrestritos. Para meus pais, Eduardo e Regina, pela inspiração constante. Para família e amigos, pela presença iluminadora. 


\section{Agradecimentos}

À minha orientadora Professora Sandra Regina da Rocha-Pinto pelo estímulo, parceria, dedicação e ensinamentos incontáveis ao longo da realização deste trabalho.

À CAPES e à PUC-Rio, pelos auxílios concedidos, sem os quais este trabalho não poderia ter sido realizado.

Aos professores Andréa Cherman e Ricardo Sarmento Costa, que participaram da comissão examinadora.

Às professoras Ana Heloísa e Alessandra Costa em nome dos demais excelentes professores do Mestrado Acadêmico do IAG/PUC-Rio, pelos tantos ensinamentos e pela disponibilidade.

A todos os funcionários do Departamento de Administração, pelo apoio constante.

Aos colegas do grupo de pesquisa, pelos debates e pelo convívio enriquecedor.

Aos colegas da turma de 2015 do Mestrado Acadêmico em Administração na PUCRio, pela companhia na jornada.

À equipe toda da Trilha e do INT (DGEP), pelos ensinamentos, pela parceria e pelo convívio estimulante.

Aos profissionais que participaram da pesquisa, por terem gentilmente cedido seu tempo e compartilhado suas experiências para a realização deste trabalho.

À minha esposa e meu filho, pelo amor e companhia que inspiram e sustentam diariamente.

Aos meus pais, pela inspiração, educação, atenção e carinho eternos.

Aos familiares e amigos tão queridos, por me estimularem, alegrarem e guiarem todos os dias. 


\section{Resumo}

Jardim, Schoemer Leandro; Rocha-Pinto, Sandra Regina da. A compreensão das competências nas rotinas de programação da produção. Rio de Janeiro, 2017, 97p. Dissertação de Mestrado - Departamento de Administração, Pontifícia Universidade Católica do Rio de Janeiro.

Nas organizações industriais contemporâneas, a competição global e o avanço das tecnologias de informação tornam os produtos e processos cada vez mais semelhantes. O desempenho operacional passa, então, a ser um dos principais mecanismos de diferenciação. Nesse cenário, a área de planejamento e programação da produção ganha um inédito papel estratégico. O presente estudo se propôs a investigar esse novo papel com um olhar centrado nas rotinas organizacionais e nas pessoas que exercem a função. Mais especificamente, a partir de uma abordagem qualitativa e interpretativa, o trabalho utilizou o método fenomenográfico para compreender como os programadores concebem a competência nas suas rotinas organizacionais. A análise das entrevistas identificou três diferentes concepções. A primeira está associada à tarefa de alocação eficiente de recursos e materiais. A segunda vê a programação como um processo de mediação entre as diferentes áreas da empresa. E a terceira atribui ao programador de produção a reponsabilidade de fazer a gestão estratégica da operação. Além disso, foram identificadas seis dimensões do fenômeno que explicam e diferenciam as concepções, são elas: Raciocínio lógico, Conhecimento técnico (do processo produtivo), Conhecimento sistêmico (de outras áreas), Estratégia de negociação, Aspecto manifesto da rotina e Envolvimento com a estratégia corporativa. Os achados sugerem, por fim, que a dimensão estratégica da programação é verificável, em diferentes graus, nas suas rotinas. Além disso, ao revelar a concepção competência como sendo a mediação entre as diferentes áreas da empresa, o estudo traz as estratégias de negociação para o centro do debate sobre a realização competente das rotinas de programação da produção.

\section{Palavras-chave}

Rotinas organizacionais; competências; programação da produção; gestão de operações 


\section{Abstract}

Jardim, Schoemer Leandro; Rocha-Pinto, Sandra Regina da (Advisor). Understanding competence in production scheduling routines. Rio de Janeiro, 2017, 97p. Dissertação de Mestrado - Departamento de Administração, Pontifícia Universidade Católica do Rio de Janeiro.

In contemporary industrial organizations, global competition and the advancement of information technologies make products and processes increasingly similar. Operational performance then becomes one of the main differentiation mechanisms. In this scenario, the area of production planning and scheduling gains an unprecedented strategic role. The present study aimed to investigate this new role with a focus on the organizational routines and the people who perform them. More specifically, from a qualitative and interpretative approach, this study used phenomenography method to understand how schedulers conceive competence in their organizational routines. The analysis of the interviews identified three different conceptions. The first is associated with the task of efficient allocation of resources and materials. The second sees scheduling as a process of mediation between the different areas of the company. And the third assigns to the production planner the responsibility to do the strategic management of the enterprise operations. In addition, six dimensions of the phenomenon that explain and differentiate the conceptions are identified: Logical reasoning, Technical knowledge (of the productive process), Systemic knowledge (of other areas), Negotiation strategy, Manifested aspect of the routine and Involvement with corporate strategy. The findings suggest that the strategic dimension of scheduling is verifiable, to different degrees, in production planning routines. In addition, by revealing the concept of competence as being the mediation between the different areas of the company, the study brings negotiation strategies to the center of the debate on the competent realization of production planning routines.

\section{Keywords}

Organizational routines; competece; production planning; operations management 


\section{Sumário}

10 problema 12

1.1. Introdução 12

1.2. Objetivo final 14

1.3. Objetivos intermediários $\quad 14$

1.4. Delimitação do estudo 15

1.5. Relevância do estudo 15

2 Referencial teórico $\quad 18$

2.1. Rotinas Organizacionais 18

2.1.1. A origem dos estudos de rotinas e seus diferentes enfoques $\quad 19$

2.1.2. Estabilidade e mudança nas rotinas 21

2.1.3. O caráter ostensivo e performativo das rotinas 22

2.1.4. Os artefatos das rotinas 23

2.1.5. Variação e experiência nas rotinas 24

2.1.6. Rotinas e aprendizagem organizacional 25

2.1.7. Interdependência nas rotinas organizacionais 26

2.2. Competências 27

2.2.1. Competência na perspectiva racionalista 28

2.2.1. Competência na perspectiva interpretativa 29

2.2.2. A racionalidade prática 30

3 Procedimentos metodológicos 32

3.1. Aspectos epistemológicos e ontológicos 32

3.2. Tipo de pesquisa 33

3.3. Abordagem da pesquisa fenomenográfica 34

3.4. A construção do espaço de resultados 35

3.4.1. Categorias descritivas 36

3.4.2. Dimensões explicativas 37

3.4.3. Espaço de resultados. 37 
3.5. Justificativa da abordagem de pesquisa 38

3.6. Coleta dos dados 39

3.6.1. Variedade dos sujeitos 39

3.6.1. Formulação do Roteiro de entrevistas 42

3.6.2. Condução das entrevistas 44

3.7. Tratamento e análise dos dados emergentes do campo 45

$\begin{array}{ll}\text { 3.7.1 Tratamento dados } & 45\end{array}$

3.7.2 Análise dados 46

3.8. Limitações da abordagem de pesquisa 48

4 Resultados encontrados $\quad \mathbf{5 0}$

4.1. As Categorias descritivas e as dimensões explicativas 51

4.1.1. Alocação de recursos e materiais 58

4.1.2. Mediação entre diferentes áreas 65

4.1.3. Gestão tático-estratégica da operação 71

4.2. O Espaço de Resultados 77

5 Considerações finais $\quad 79$

6 Referências bibliográficas $\quad 87$

$\begin{array}{ll}\text { Apêndice I. Roteiro semiestruturado } & 95\end{array}$

Apêndice II. Lista de termos específicos $\quad 97$ 


\section{Lista de Figuras}

Figura 1 - Hierarquia entre as categorias descritivas 


\section{Lista de Quadros}

Quadro 1 - Caracterização dos sujeitos que participaram do estudo

Quadro 2 - Espaço de resultados (outcome space) das concepções de competência nas rotinas organizacionais de programação da produção (1/2). Elaborado pelo autor.

Quadro 3 - Espaço de resultados (outcome space) das concepções de competência nas rotinas organizacionais de programação da produção (2/2). Elaborado pelo autor. 


\section{1 \\ O problema}

\section{1. Introdução}

Em um mundo globalizado, com a circulação de informações veloz e incessante, tanto as inovações tecnológicas quanto as características dos produtos e processos ofertados pela indústria estão cada vez mais semelhantes. Em decorrência, nos últimos anos, a função de gestão de operações no chão-de-fábrica e, mais especificamente, a atividade de programação da produção, ganham crescente relevância estratégica para a competitividade das empresas. A operação, isto é, a maneira pela qual as empresas agem e reagem em relação às dinâmicas do mercado, torna-se um dos principais mecanismos de diferenciação. (HILL e HILL, 2009; SHIELDS e MALHOTRA, 2008; CARVALHO, 2005).

O programador de produção, em que pese os limites à prática racional de sua função (SIMON, 1947; CYERT e MARCH, 1963) toma decisões a partir de um problema combinatório explosivo ao mesmo tempo em que intermedia os objetivos das áreas comercial e produtiva das empresas. Objetivos estes que são frequentemente contraditórios e mensurados por indicadores conflitantes (COSTA e JARDIM, 2015; CARVALHO, 2005, SAISSE e WILDING, 1997). Alguns autores apontam metodologias e ferramentas de gestão da capacidade produtiva para lidar com o conflito da tomada de decisão com objetivos antagônicos (BROWN, MARIN e SCHERER, 1995; COSTA, 1996; THOMAS et al, 1997; CARVALHO, 2005). Outros autores, como Quinn e Novels (2011) e LaForge e Craighead (2000), dão atenção especial às soluções baseadas em tecnologia da informação e nos de sistemas corporativos, os chamados softwares de APS (Advanced Planning and Scheduling). Nota-se, portanto, que essas abordagens são racionalistas, centradas em uma perspectiva tecnológica e funcional, e que tendem a não levar em consideração a dimensão das competências profissionais e a percepção de quem efetivamente exerce a função. 
No entanto, as abordagens racionalistas não são a única maneira de se compreender as múltiplas dimensões envolvidas no estudo das organizações. Nas últimas décadas, outras abordagens, como o paradigma interpretativista, por exemplo, têm criticado o funcionalismo por desconsiderar a natureza contextual e subjetiva dos fenômenos (MORGAN, 2005; VERGARA e CALDAS, 2005;). Para Morgan (2005), o paradigma interpretativista se baseia no entendimento de que a experiência social não é constituída por uma única realidade objetiva, mas por um conjunto de interpretações subjetivas e jogos de linguagem. Em paralelo, e considerando o âmbito específico da área de programação da produção, alguns autores (MACCARTHY, WILSON e CRAWFORD, 2001; RITTER, SOHAL e D’NETTO, 1998) têm destacado nos últimos anos que, apesar dos avanços tecnológicos, na maioria das organizações industriais, as rotinas organizacionais de planejamento e programação ainda dependem significativamente da competência humana na tomada de decisão para garantir um desempenho considerado eficaz. Nesse sentido, em um seminal estudo sobre competência humana no trabalho, Sandberg (2000) faz uma crítica à abordagem funcionalista da competência, que restringe o bom desempenho profissional a uma lista universal de habilidades e conhecimentos. Para o autor, a competência na realização de uma tarefa não pode ser separada do trabalho em si, nem dissociada do entendimento que cada pessoa tem do trabalho que excuta.

Esse contexto geral levanta algumas importantes questões, tanto sobre a natureza da área de planejamento e programação da produção, quanto sobre a percepção dos programadores acerca do que é a competência na realização de suas rotinas. Os programadores de produção reconhecem um papel estratégico em sua função? É possível identificar em suas descrições sobre as rotinas organizacionais aspectos que reflitam esse novo papel? Como os programadores de produção concebem a competência para a realização de tais rotinas? As concepções de competência formuladas pelos programadores de produção levam em consideração uma relação direta com as estratégias organizacionais? A busca por respostas a esses questionamentos está no cerne da motivação do presente estudo.

Para investigar o fenômeno e responder a tais perguntas, portanto, optou-se pela abordagem interpretativista e pelo método da fenomenografia. Em suma, a intenção 
deste trabalho é entender a competência de programação da produção a partir do significado que as rotinas organizacionais têm para o programador que as vivencia, tomando-se como base os relatos de sua experiência.

\section{2.}

\section{Objetivo final}

O presente estudo tem como ponto de partida o contexto de mudança no qual a função de planejamento de produção está inserida. De maneira geral, espera-se compreender os aspectos ostensivo e performativo das rotinas de planejamento e programação da produção, levando em consideração também os artefatos utilizados (TURNER e FERN, 2012; PARMIGIANI e HOWARD-GRENVILLE, 2011; FELDMAN e ORLIKOWSKI, 2011; PENTLAND e FELDMAN, 2005). De maneira mais específica, o estudo pretende compreender como a competência é concebida pelos programadores no âmbito das rotinas organizacionais de planejamento e controle da produção.

\section{3.}

\section{Objetivos intermediários}

No intuito de responder à questão central de pesquisa proposta por esse trabalho e abordar os objetivos gerais aqui propostos, estabeleceu-se o seguinte percurso para este estudo.

- Revisar a evolução teórica e o debate acadêmico contemporâneo envolvido nas discussões sobre rotinas organizacionais e competências sob uma perspectiva interpretativa;

- Analisar como os programadores de produção descrevem as rotinas de programação da produção;

- Analisar os diferentes modos pelos quais os indivíduos percebem e experimentam a programação de produção; 
- Descrever qualitativamente os diferentes modos pelos quais os programadores de produção definem a competência na execução das rotinas organizacionais de programação da produção;

- Descrever os relacionamentos lógicos entre os diferentes modos, mediante os quais, os programadores buscam compreender a competência nos rotinas de programação da produção.

1.4.

Delimitação do estudo

O presente estudo terá como campo de análise as rotinas organizacionais de programação da produção em organizações industriais. A pesquisa procurará compreender as concepções de competência de acordo com o relato de indivíduos que possuem diferentes posições hierárquicas dentro dessas rotinas.

A abordagem geral do presente estudo parte de uma perspectiva interpretativista (SANDBERG, 2000). A partir do método fenomenográfico (AKERLIND, 2005; MARTON, 1981), a competência para programação da produção será analisada com base na experiência vivida do programador. O estudo procurará capturar as concepções de competência existentes nas rotinas organizacionais e a maneira como elas variam e se relacionam entre si.

\section{5.}

Relevância do estudo

As percepções da academia sobre o papel da área de planejamento e programação da produção nas organizações industriais vêm se modificando nos últimos anos. No âmbito da competição global, a gestão da operação tem assumido gradualmente um caráter estratégico (HILL e HILL, 2009). Correa (2003) chama atenção ainda para o fato de que na chamada "nova economia" os principais produtos e ativos das empresas passam a ser de natureza intelectual (informação e conhecimento). Nesse contexto, aspectos diretamente impactados pelo planejamento e programação da produção, como flexibilidade, velocidade, pontualidade e qualidade, vêm se se transformando nos 
principais diferenciais competitivos das organizações industriais (COSTA e JARDIM, 2015; CARVALHO, 2005,). O presente estudo pretende verificar, portanto, como esse cenário se reflete na prática dos programadores.

Em estudo sobre as relações funcionais de poder nas organizações, Shields e Malhotra (2008) revelaram que, ao contrário do que estabeleciam afirmações anteriores na literatura sobre estratégias de fabricação, os gerentes industriais já percebem a produção como uma das áreas que tem mais poder dentro das empresas. O estudo indica que os gerentes industriais tomam ações para melhorar seu papel nas decisões estratégicas no nível dos negócios e são proativos no aumento do poder de suas próprias áreas funcionais. Nesse sentido, o presente estudo também apresenta uma contribuição relevante ao investigar a maneira como esse papel estratégico se reflete nas percepções que os programadores de produção fazem acerca das rotinas organizacionais e da sua respectiva realização competente.

Além disso, em se considerando o plano específico das atividades de programação da produção, outros estudos indicam que o ideal de automação vem sendo gradualmente substituído por uma revalorização papel humano na tomada de decisão (MACCARTHY, WILSON e CRAWFORD, 2001; RITTER, SOHAL e D’NETTO, 1998). Ou seja, à medida que o entusiasmo pela otimização baseada exclusivamente em software diminui, o papel decisivo no desempenho organizacional passa a ser atribuído à dimensão da competência humana na tomada de decisão no chão-de-fábrica (MACCARTHY, WILSON e CRAWFORD, 2001). Mais especificamente, em relação à dimensão da competência Ritter, Sohal e D’Netto (1998) fizeram um estudo quantitativo e funcionalista que listou uma série de habilidades requeridas para a excelência de um programador de produção. Dentre elas, destacavam-se a habilidade para manejar mudanças, comunicação, e a capacidade de desenvolvimento ou execução de planos. E também apareciam, mesmo que ainda marginalmente, habilidades como empatia, ambição e capacidade de operar em rede. Nesse sentido, é possível dizer que, ainda que aspectos da dimensão humana já tenham seu papel sutilmente reconhecido e abordado, ainda faltam mais estudos que considerem as dimensões contextuais e subjetivas da competência no âmbito das rotinas organizacionais de planejamento e 
programação da produção. $\mathrm{O}$ presente estudo pretende contribuir para o preenchimento desta lacuna.

Desta forma, se por um lado existem tecnologias computacionais e métodos racionalistas que definem boas práticas dos chamados departamentos de PCP (Planejamento e Controle da Produção), pode-se dizer que a sua natureza contextual ainda não foi suficientemente estudada, especialmente tendo como base o arcabouço teórico das rotinas organizacionais (PARMIGIANI e HOWARD-GRENVILLE, 2011; FELDMAN e ORLIKOWSKI, 2011; PENTLAND e FELDMAN, 2005).

Em suma, levando-se em conta a crescente relevância estratégica da programação de produção, pode-se dizer, por fim, que a dimensão da competência humana nas rotinas organizacionais de planejamento e programação da produção, sob uma perspectiva interpretativa e baseada na vivência (SANDBERG, 2000), não foi tema de estudos suficientes. É precisamente este o objeto do presente estudo. 


\section{2 Referencial teórico}

Nesse capítulo, o objetivo será percorrer as principais correntes teóricas que inspiram e respaldam o estudo. Levando-se em consideração o objetivo de compreender o que constitui a competência no âmbito das rotinas organizacionais de programação da produção, há dois construtos centrais nos quais se aprofundar: rotinas organizacionais e competências. Em relação ao primeiro, pretende-se explorar, dentre outras coisas, seus aspectos ostensivo e performativo, a utilização de artefatos e a sua contribuição mútua para a estabilidade e a mudança (TURNER e FERN, 2012; PARMIGIANI e HOWARD-GRENVILLE, 2011; FELDMAN e ORLIKOWSKI, 2011; PENTLAND e FELDMAN, 2005). Já a competências será abordada a partir de uma visão interpretativa, considerando que a maneira como as pessoas vivenciam o trabalho é mais relevante para a compreensão de sua competência do que uma análise instrumental de alguma lista de atributos universalmente desejáveis. (PINNINGTON e SANDBERG, 2013; PINNINGTON e SANDBERG, 2014, SANDBERG, 2000).

\section{1. Rotinas Organizacionais}

É comum em distintas disciplinas científicas, desde a geologia até a medicina, que se procure entender a estrutura interna pela qual os fenômenos ocorrem. O mesmo vale para os estudos de rotinas organizacionais, conforme afirmam Pentland e Feldman (2005). No entanto, em que pese a atualidade do tema, o próprio conceito de rotina ainda não está plenamente consolidado. Milagres (2011) explora esse ponto. A autora mostra que há um grupo de pesquisadores que associa o conceito de rotinas à ideia de padrão, com destaque para a obra de Winter (2000). Para um segundo grupo, centrado na seminal obra de Cyert e March (1963), o conceito que melhor define as rotinas são as regras, isto é, os conjuntos de procedimentos operacionais e decisórios já preestabelecidos. Ainda segundo Milagres (2011), há um terceiro grupo que define as rotinas, de maneira mais complexa e detalhada, como "disposições coletivas que levam 
os agentes a praticarem comportamentos adquiridos ou adotados previamente, que são colocados em prática mediante determinados estímulos ou contexto (BECKER; SALVATORE e ZIRPOLI, 2005)".

Indo além dessa definição em torno de padrões, regras ou disposições coletivas, parece relevante também o destaque que Pentland e Feldman (2005) dão à noção de que, ao utilizar as rotinas como unidade de análise organizacional, é preciso reconhecer também que elas são constituídas por aspectos específicos e abstratos, além de comumente permeadas por artefatos físicos presentes em sua realização. Nesse mesmo trabalho, os autores mostram como a profundidade e a complexidade do conceito de rotinas possibilita ainda a assimilação de outra ambiguidade determinante: as rotinas representam estabilidade e mudança. Sua estrutura interna pode ser compreendida como um amplo espectro que tem a estabilidade total em uma ponta e a mudança constante na outra, variando de acordo com as circunstâncias particulares de cada situação.

Por fim, vale destacar, conforme demonstram Parmigiani e Howard-Grenville (2011), que alguns estudos anteriores de Dodgson (1993) e Levitt e March (1988) colocam a aprendizagem organizacional como sendo "baseada em rotinas" (routinebased), o que significa que a aprendizagem seria ao mesmo tempo viabilizada e limitada pelas rotinas.

\subsection{1.}

\section{A origem dos estudos de rotinas e seus diferentes enfoques}

Assim como ainda existe alguma divergência sobre a delimitação precisa do conceito de rotinas, há também diferentes percepções sobre suas origens. Para Parmigiani e Howard-Grenville (2011), a exemplo de outras ideias fundamentais no campo organizacional, o conceito de rotinas remonta marcadamente à Carnegie School (CYERT e MARCH, 1963; MARCH e SIMON, 1958; SIMON, 1947). Em consonância com esse ponto de partida, Milagres (2011) o desdobra em três vertentes. Duas delas associam o enfoque das rotinas ao indivíduo: são as habilidades e os hábitos. Na influente classificação de Parmigiani e Howard-Grenville essa mesma divisão foi organizada em duas grandes perspectivas distintas, a baseada em habilidades 
(Capabilities Perspective) e a baseada na prática (Practice Perspective). Já o terceiro desdobramento, por sua vez, considera que as rotinas se originam na própria organização. Diz respeito aos mecanismos de aprendizagem por tentativa e erro, que aos poucos vão se consolidando como rotinas consagradas.

A ênfase no hábito (ou Practice Perspective), como mostram Parmigiani e Howard-Grenville (2011), tem origem no trabalho de Dewey (1922). Mais recentemente, Hogson e Knudesn (2004) afirmam que o hábito é essencial para lidar com a complexidade, porque reduz o esforço de cálculo, o custo de aquisição de informações, e conserva, assim, os esforços mentais (Milagre, 2011). Tal entendimento estaria de acordo com as visões de Cyert e March (1963), atualizadas por Argote e Greve (2007), de que padrões de comportamento favorecem a efetividade das tomadas de decisão, das resoluções de conflito e das necessidades de adaptação a mudanças ambientais, conforme apontam Parmigiani e Howard-Grenville (2011).

Segundo essas autoras, a visão das rotinas como uma metáfora para as habilidades individuais (ou Capabilities Perspective), por sua vez, está fortemente ancorada na obra de Winter e Nelson (1982). Milgares (2011) complementa tal visão, acrescentando que estes mesmos autores entendem as habilidades como sendo contexto-dependentes, além de envolverem um conjunto de escolhas, ou uma sequência de regras, que podem ser automatizadas em prol da eficiência da rotina.

Por fim, para explicar a terceira frente, em que as rotinas são entendidas como decorrência de processos organizacionais de tentativa e erro, Milagres (2011) parte da premissa geral de que as organizações se movem em torno de objetivos. Para atingilos, introduzem variações no comportamento. As variações bem-sucedidas tendem a ser repetidas e endossadas até o ponto de se tornarem rotineiras. Rerup e Feldman (2011) partem de Gong, Baker e Miner (2005) para aprofundar essa ideia. No trabalho citado, Gong, Baker e Miner (2005) afirmam que quando uma organização considera que não cumpriu os seus níveis de aspiração, o que constitui um problema, ela também tenderá a elaborar uma rotina para resolvê-lo. Do mesmo modo, portanto, se uma rotina falha em resolver um problema, a organização a substitui, ou revisa, ou experimenta de outro jeito, ou procura em seu ambiente outras ainda mais novas para testar. Há notadamente aí um mecanismo de aprendizagem por tentativa-e-erro, a exemplo dos 
apontados por Rerup e Feldman (2011). Pode-se dizer que a importância desse tipo de aprendizagem é reforçada por Turner e Fern (2012) quando relatam que os indivíduos com mais experiência tendem a responder melhor a mudanças de contexto.

\subsection{2.}

\section{Estabilidade e mudança nas rotinas}

A partir os trabalhos de Becker (2004) e Cohen et al. (1996), Turner e Fern (2012) sugerem que muita atenção já foi dada ao aspecto de que as rotinas ao mesmo tempo contribuem para garantir estabilidade, mas também se adaptam a mudanças de contexto. Segundo os autores, tanto a estabilidade quanto a mudança refletem a maneira como a performance das rotinas é percebida segundo a racionalidade limitada dos indivíduos envolvidos nela. Turner e Fern (2012) exploram o conceito de "rotinas dinâmicas" para explicar como a mudança de rotinas é capaz de ocorrer de maneira estável. Ou seja, ao contrário do que poderia parecer, as rotinas, na verdade, ajudam as organizações a se transformarem.

Esse caráter, digamos, "mutável mas estável" é precisamente ilustrado por Feldman e Orlikowski (2011) com a imagem de um ciclo. Ideias ou ideais, segundo as palavras de Feldman (2000), se convertem em planos. Estes se manifestam em ações e, por conseguinte, geram resultados. Uma avaliação de tais resultados pode provocar o desejo de reparação de algum procedimento, por exemplo, ou ensejar uma variação mais ousada de sua prática, ou simplesmente estimular sua expansão para ampliar as consequências. Em outras palavras, o ciclo é estável, mas é já um novo, e só um pouco diferente, a cada vez em que é rodado.

A partir dos achados de outros estudos, Pentland e Feldman (2005) apontam ainda duas questões importantes acerca de estabilidade e mudança das rotinas. Em primeiro lugar, lembram que é possível que um aspecto de uma rotina se mantenha imutável enquanto outro seja relativamente variável. Além disso, complementam os autores, pode haver também uma significativa dissonância entre o que os pesquisadores entendem como sendo uma mudança na rotina e a maneira como compreendem a mesma situação os membros da organização. Há relatos de completa divergência. 
Assim, a harmonia entre estabilidade e mudança das rotinas também encontra seus limites. Parmigiani e Howard-Grenville (2011) evocam alguns estudos que apontam para determinadas contingências, ou condições de contorno, que são decisivas nessa mediação de "forças conflitantes". Elas mostram como Adler et al. (1999) consideram a confiança, a liderança e o treinamento como fatores determinantes para a maior ou menor flexibilidade das rotinas. Mostram também, a partir dos trabalhos de Collinson e Wilson (2006), Dyer e Hatch (2006), Szulanski (1996), que o caráter interdependente das rotinas pode levar à rigidez e dificuldade de mudança. Por fim, ainda citam aspectos críticos mais gerais como a cultura organizacional, os fatores tecnológicos e influências externas. Diferentes exemplos e situações pesquisadas corroboram a ideia de que tudo isso restringe a capacidade de mudança das rotinas organizacionais.

\subsection{3.}

\section{O caráter ostensivo e performativo das rotinas}

Uma característica recorrentemente abordada nos estudos das rotinas organizacionais é a que as descreve segundo seus aspectos ostensivo e performativo. $\mathrm{O}$ conceito que está por trás dessas expressões é o de que, por um lado, as rotinas são constituídas por padrões abstratos (ostensive) reconhecidos pelos membros da organização. Por outro, estes mesmos membros realizam ações (performative) em seu dia a dia segundo o entendimento particular que fazem das rotinas. Ou seja, a literatura sobre o tema indica que a maneira como as pessoas entendem ou concebem uma rotina pode ser dissonante daquelas com que elas a atuam na prática cotidiana.

Performances, nesse contexto, nas palavras de Pentland e Feldman (2005), são “as ações específicas tomadas por pessoas específicas em momentos específicos quando elas estão engajadas no que entendem ser uma rotina da organização". Ainda segundo os autores, o caráter performativo, portanto, está relacionado às práticas. Mesmo que estas decorram de um contexto de regras e expectativas compartilhadas, no momento em que um indivíduo as transforma em ação, haverá sempre um aspecto de inevitável improviso e, po rtanto, novidade. 
Já o caráter ostensivo das rotinas, em contrapartida, ainda segundo Pentland e Feldman (idem) tem natureza abstrata e pode ser entendido pela metáfora de uma narrativa. No entanto, Feldman e Orlikowski (2011) comentam que os aspectos ostensivos são também múltiplos, uma vez que sempre dependem de um ponto de vista e normalmente estão mal representados por regras escritas ou procedimentos formais. Ou seja, por ser abstrato, não se pode deixar de considerar que o entendimento sobre um padrão varia "de pessoa para pessoa, de evento para evento, de momento para o momento" (PENTLAND e FELDMAN, 2005).

\subsection{4.}

\section{Os artefatos das rotinas}

A perspectiva prática das rotinas também tem sido representada pela metáfora de uma "caixa-preta", cujos conteúdos e mecanismos precisariam ser esmiuçados, levando-se em conta seus contextos de realização (PARMIGIANI e HOWARDGRENVILLE, 2011). Nesse sentido, vêm ganhando importância os estudos sobre os artefatos utilizados no referido processo de operacionalização das rotinas. Para Pentland e Feldman (2005), os artefatos são as "manifestações físicas" das rotinas. Tal definição engloba desde as regras formais de um processo até computadores instrumentados para suporte à decisão, passando também pelo próprio layout das organizações, por exemplo.

No fundo, ainda segundo os autores, os artefatos consubstanciam a intenção de padronizar as práticas de trabalho. Um bom exemplo disso seriam os sistemas empresariais de TI. No entanto, os artefatos esbarram sempre na multiplicidade de variações de contexto, o que interfere decisivamente neles. Assim, baseando-se em alguns estudos (GARFINKEL, 1967; ZIMMERMAN, 1970; GIDDENS, 1984; HERITAGE, 1984; TAYLOR, 1993), os autores mostram que os artefatos acabam sendo recursos para instrumentar a ação, sem necessariamente determinar pormenorizadamente a prática em que são utilizados. Outra maneira pela qual os estudiosos se apropriam dos artefatos é tomando-os como fontes indicativas que ajudam a compreender alguns aspectos ostensivos das rotinas. E Pentland e Feldman (2005) ainda complementam esse ponto afirmando que os artefatos despertam o 
interesse dos estudos organizacionais justamente porque apresentam um maior grau de estabilidade, ainda que relativo.

Parmigiani e Howard-Grenville (2011) mostram ainda que os acadêmicos ligados à perspectiva que relaciona as rotinas a habilidades (Capabilities perspective) dão uma atenção especial aos artefatos tangíveis, como tecnologias específicas e equipamentos. Para esses autores, é importante considerar os desdobramentos dos artefatos físicos na performance das rotinas. Estudando, por exemplo, como os aspectos de uma rotina que estejam codificados em um software são capazes de potencializar a maneira pela qual os indivíduos a vivenciam e se comportam diante dela.

\subsection{5.}

Variação e experiência nas rotinas

Conforme visto, pode-se dizer que as rotinas estão em larga medida submetidas à interpretação, é inerente a elas um considerável grau de subjetividade. Não se pode, portanto, definir, delimitar ou analisá-las de maneira simplesmente objetiva. E isso é importante porque significa que há inúmeros desafios tanto para as organizações quanto para quem as estuda.

Pentland e Feldman (2005) chamam atenção para o fato de que a maneira como se executa uma rotina, seu caráter performativo, pode divergir significativamente do padrão reconhecido, que é seu caráter ostensivo. E ambos podem ainda divergir do artefato atribuído a essa mesma rotina. Além disso, nem sempre é claramente reconhecível o ponto onde uma rotina acaba e outra se inicia. Com base no seminal trabalho de Latour (1986), os autores sugerem que a delimitação dos contornos de uma rotina se dá partir de uma "capa", ou de um "revestimento", que é colocado pelo observador a partir do olhar e da vivência.

Na mesma linha, não é difícil compreender que o caráter performativo de uma rotina também varie no tempo. Primeiro, uma pessoa pode não conseguir executar (performative) uma rotina da forma pretendida (ostensive). Depois, conforme realiza diariamente a rotina, ela tende a ir adaptando as práticas de acordo com o sucesso, a precisão ou fracasso dos mecanismos envolvidos. Ou até mesmo pelo advento de maneiras mais práticas ou rápidas de executar as tarefas, em um processo já 
denominado aqui de tentativa-e-erro (PARMIGIANI e HOWARD-GRENVILLE, 2011; FELDMAN, 2000; RERUP e FELDMAN, 2011).

Como uma forma de responder a essa característica subjetiva e aberta das rotinas, portanto, Turner e Fern (2012) trabalham com a ideia de que a experiência na prática das rotinas reduz as divergências. A partir de dados do campo de seu estudo, os autores mostram como a experiência e familiaridade dos atores contribui em distintas frentes, afetando positivamente tanto o desempenho, quanto a estabilidade e até mesmo a variabilidade das rotinas. Seu estudo revela que, quanto maior a experiência do ator, menor a divergência com o desempenho histórico da rotina.

\subsection{6.}

\section{Rotinas e aprendizagem organizacional}

A partir da experiência, segundo Turner e Fern (2012), surgem entre os atores da rotina novos entendimentos que podem se desdobrar em conhecimento e aprendizado. Pentland e Feldman (2005) afirmam de maneira explícita, com base em autores como Levitt e March (1988) e Miner (1990), que as rotinas organizacionais são fontes de aprendizagem organizacional. Isso se dá especialmente a partir das reflexões produzidas nos ciclos de mudança e estabilidade, e na aprendizagem resultante dos processos de tentativa-e-erro (FELDMAN, 2000; PARMIGIANI e HOWARDGRENVILLE, 2011). A aprendizagem dos atores nesses processos também amplia sua percepção sobre as possibilidades alternativas de realização da rotina (TURNER e FERN, 2012). Com isso, pode-se dizer que tal processo se dá numa via de mão dupla: as rotinas não só geram aprendizagem, como igualmente a aprendizagem gera rotinas (PARMIGIANI e HOWARD-GRENVILLE, 2011).

Uma abordagem complementar defende que as rotinas organizacionais proporcionam aprendizado e mudança porque são repositórios de conhecimento, porque compõem a memória da organização (PARMIGIANI e HOWARDGRENVILLE, 2011; MILAGRES, 2011). Ampliando a reflexão sobre esse aspecto, Parmigiani e Howard-Grenville (2011) afirmam ainda que "um considerável grau de aprendizagem organizacional ocorre via transferência de conhecimentos com 
organizações externas”. Tal aspecto dá destaque também ao papel das rotinas que se estendem externamente, entre organizações.

Por fim, a noção de que as rotinas possuem um aspecto ostensivo e outro performativo também tem sido útil para fazer a ponte entre as perspectivas conscientes e inconscientes da aprendizagem organizacional, conforme propõem Feldman e Orlikowski (2011) a partir de Levinthal e Rerup (2006). As autoras chamam atenção para os pesquisadores que trabalham com uma ontologia prática (por exemplo, GHERARDI, 2006; e LAVE, 1988). Para eles, as práticas são fundamentais para a própria produção de realidade em si. Um paralelo, portanto, é feito em relação às rotinas, sugerindo que dessa forma elas têm impacto direto na geração de conhecimento e aprendizado.

\subsection{7. Interdependência nas rotinas organizacionais}

A literatura sobre rotinas organizacionais, especialmente a filiada à perspectiva prática (FELDMAN e ORLIKOWSKI, 2011), chama atenção também para as relações de interdependência nas rotinas organizacionais. Deken et al (2016) partem de conceitos como os fenômenos mutuamente constitutivos (BRADBURY e LICHTENSTEIN, 2000) e o caráter relacional da agência (EMIRBAYER 1997, EMIRBAYER e MISCHE, 1998) para explicar o que definem como a "abordagem relacional" do estudo das rotinas organizacionais. Segundo os autores, o que caracteriza essa abordagem é um entendimento de que tanto o fenômeno quanto a agência possuem propriedades relacionais que são constitutivas de sua natureza e, portanto, determinantes para seu funcionamento e entendimento.

Em estudo para compreender a relação entre atores envolvidos em rotinas interdependentes, Carlile (2004) encontrou três dimensões que, simultaneamente, estruturam essa relação: novidade, dependência e diferença. A novidade se caracteriza pela mudança em relação a alguma prática passada. Sua importância se dá com base na noção de que as ações passadas tendem a ser uma referência para ações presentes. A novidade, portanto, traz alguma turbulência à estabilidade das rotinas, proporcionando desafios para as ações interdependentes. Autores como Carlile (2004) e Pentland et al 
(2012) entendem a interpendência como sendo o conjunto das dependências entre as ações. Assim, a dimensão da dependência vai dizer respeito às consequências que uma ação tem para outras. O desafio que se coloca aos atores, então, é identificar e responder a essas consequências em situações de novidade nas rotinas (DEKEN et al 2016, CARLILE, 2004). Ainda segundo os autores, a última dimensão, diferença, refere-se aos modos distintos pelos quais os fenômenos, as rotinas e as relações são experimentados.

Nesse sentido, a ênfase no caráter independente das rotinas pressupõe uma leitura dos fenômenos organizacionais consciente de que os atores podem ter entendimentos distintos sobre as situações de novidade nas rotinas, podem perceber de modo distinto as suas respectivas consequências para as outras rotinas, e podem ainda variar na compreensão do que constitui uma melhor performance da rotina diante da novidade (DEKEN et al, 2016; CARLILE, 2004; PENTLAND E FELDMAN, 2005; TURNER e RINDOVA, 2012).

\section{2. Competências}

Desde a publicação de seu seminal trabalho Human Competence at work (2000), e especialmente nos últimos cinco anos, Jörgen Sandberg vêm se tornado uma incontestável referência para o estudo de Competências sob uma perspectiva interpretativista. Utilizando-se como base os indicadores levantados pela ferramenta Google Scholar, por exemplo, podemos encontrar mais de 1.100 citações ao artigo mencionado acima. Número que, somado aos demais, de suas outras publicações em periódicos internacionais desde então, totalizam uma quantidade superior a 5.000 citações (sendo que 60\% deste total se referem a textos publicados a partir de 2011). No artigo em questão, assim como em outros mais recentes (PINNINGTON e SANDBERG, 2013; PINNINGTON e SANDBERG, 2014; LAMB, SANDBERG \& LIESCH, 2011), percebe-se que uma das perguntas centrais que rege seu trabalho diz respeito à investigação sobre o que constitui competência no trabalho. Para responder a ela, os autores defendem a utilização de uma abordagem interpretativista, geralmente consubstanciada no método de pesquisa fenomenográfico. 
Estudando o trabalho de engenheiros de otimização de motores, Sandberg (2000) parte da premissa de que a competência é um problema de gestão fundamental. Sua origem, segundo o autor, remonta aos clássicos estudos Tayloristas de tempos e movimentos, quando a competência era reduzida a um conjunto funcional de regras, leis e fórmulas. A partir daí, desenvolveu-se uma abordagem racionalista do tema, em que a competência foi sendo definida por um conjunto específico de atributos, conhecimentos e habilidades.

Alternativamente, estudos mais recentes (PINNINGTON e SANDBERG, 2013; PINNINGTON e SANDBERG, 2014; LAMB, SANDBERG \& LIESCH, 2011; SANDBERG, 2000) passam a entender a competência como sendo constituída pelo significado que o trabalho tem para aquele que o realiza, isto é, partindo de sua experiência. Nesse sentido, é necessário reconhecer a variação nas práticas, mas também nas distintas influências de cada contexto. Em um desses trabalhos, Pinnington e Sandberg (2014) estudam a competência profissional associada à mobilidade de carreira em processos de internacionalização de uma empresa de serviços. Como resultado do estudo, identificaram quatro regimes de competências (técnicos, gerentes de projeto, analistas competitivos e estrategistas globais) que contribuem não só para a estratégia, mas também para o desempenho dos empregados e a formação de suas competências profissionais. Nesse sentido, sugerem a criação de sistemáticas específicas baseadas nesses regimes, o que poderia potencializar resultados tanto para os processos de internacionalização das empresas quanto para o desenvolvimento de carreira dos seus colaboradores. Antes, os mesmos autores já haviam pesquisado a relação entre a competência e a inclusão de mulheres como sócias em firmas de advocacia (PINNINGTON e SANDBERG, 2013). No referido estudo, demonstram como algumas formulações dominantes sobre a competência no trabalho das firmas de advocacia não levam em consideração a diversidade de gêneros, prejudicando assim as chances de mulheres se tornarem sócias nessas empresas.

\subsection{1.}

Competência na perspectiva racionalista 
Para a formulação de trabalhos como os citados acima (PINNINGTON e SANDBERG, 2013; PINNINGTON e SANDBERG, 2014; LAMB, SANDBERG \& LIESCH, 2011; SANDBERG, 2000), os pesquisadores estabelecem um contraponto à tradicional visão racionalista de competência. Segundo Sandberg (2000), é possível identificar três abordagens distintas nessa perspectiva racionalista: a baseada no trabalhador, a baseada no trabalho, e a mista. Ainda segundo o autor, a visão baseada no trabalhador (worker-oriented) é aquela que está centrada nos atributos humanos, tipicamente representada pelos chamados KSAs (Knowledge, Skills, Abilities) ou CHAs (Conhecimentos, Habilidades e Atitudes). É criticada por produzir descrições de competência excessivamente generalistas. A visão baseada no trabalho (workoriented), por sua vez, apresenta a vantagem de chegar a descrições de competência mais concretas e detalhadas. No entanto, também sofre críticas que se referem ao fato de uma lista de atividades ser insuficiente e limitada para indicar os atributos requeridos a um profissional. Ainda segundo o autor, a visão mista seria apenas uma combinação das duas anteriores, carregando consigo, tanto as prerrogativas funcionais de ambas quanto as críticas que recebem.

\subsection{1. \\ Competência na perspectiva interpretativa}

Os estudos da linha interpretativa (PINNINGTON e SANDBERG, 2013; PINNINGTON e SANDBERG, 2014; SANDBERG, 2000), portanto, apontam para a percepção de que os atributos usados para realização de um trabalho efetivo não são livres do contexto em que estão inseridos. Pelo contrário, são situacionais e dependentes dele. Além disso, não é raro que divirjam significativamente da maneira como estão descritos em manuais de treinamento e descrições de cargo. Assim, nos mostram que a maneira como as pessoas vivenciam o trabalho é mais relevante para a sua competência do que os atributos por si só.

Assim, para lidar com os fenômenos a partir de suas dimensões prática e contextual, esses autores vão trabalhar a partir de métodos de pesquisa qualitativos, como a análise do discurso e a etnometodologia (BOLANDER e SANDBERG, 2013), a etnografia (JOHNSTON e SANDBERG, 2008) e, com especial interesse, a 
fenomenografia (SCHEMBRI E SANDBERG, 2011; LAMB, SANDBERG e LIESCH, 2011, SANDBERG, 2000). Na fenomenografia, o mais recorrente deles, o objetivo será descrever as possíveis variações entre as concepções de competência dos trabalhadores. O termo concepção (o modo como alguém concebe algo) se refere à maneira como cada um experimenta ou constrói sentido ao mundo. É a relação indissolúvel entre o que é concebido (com o significado da realidade) e a maneira como é concebido (as práticas em que as concepções surgem).

\subsection{2.}

\section{A racionalidade prática}

A abordagem interpretativa e o método fenomenográfico, preconizados pelo trabalho seminal de Sandberg (2000), também serviram de inspiração para estudos do autor e de seus pares sobre outros temas igualmente relevantes à área de administração. Especificamente, a experiência de consumo (SCHEMBRI e SANDBERG, 2011), a seleção de empregados associada à tomada de decisão (BOLANDER e SANDBERG, 2013) e o desenvolvimento profissional (DALL'ALBA e SANDBERG, 2006). Em comum, esses trabalhos tem a preocupação de encontrar as concepções baseadas na experiência vivida de cada público que é objeto de estudo. Isto é, utilizando como base analítica a racionalidade prática.

De forma a explorar as prerrogativas da racionalidade prática, portanto, Sandberg se uniu a alguns desses e outros pesquisadores no desenvolvimento de ensaios teóricos exploratórios e propositivos. As teorias desenvolvidas sob a perspectiva de uma racionalidade científica são percebidas como insuficientes para estudar a prática organizacional, justamente porque não conseguem capturar sua lógica. Alternativamente, os autores propõem a lógica da racionalidade prática como forma de preencher a lacuna entre teoria e prática nas organizações (SANDBERG e TSOUKAS, 2011; SANDBERG e DALL'ALBA, 2009). Ela proporciona a geração de uma teoria articulada com a lógica da prática. Em outras palavras, segundo Sandberg e Tsoukas (2011), a perspectiva da racionalidade prática oferece uma estrutura ontológica e epistemológica coerente e que, em conjunto com as demais formas sistemáticas de desenvolvimento de teoria, permitem fundamentar as emergentes abordagens dos 
estudos organizacionais que se baseiam na observação prática. É o que também pode ser entendido como uma "life-world perspective", conforme a denominação de Sandberg e Dall'Alba (2009). O presente estudo, portanto, está alinhado com a ideia de Sandberg e Dall'Alba (2009) de que a adoção da "perspectiva mundo-vida" (em tradução literal) aproxima os estudos organizacionais da maneira como a prática é efetivamente constituída, permitindo que seu desempenho seja examinado mais de perto, e trazendo à tona a maneira pela qual a prática é constituída no entrelaçamento (entwinement) entre pessoas e coisas na organização. 


\section{3 Procedimentos metodológicos}

O objetivo deste capítulo é apresentar e justificar a metodologia proposta para o presente estudo. A partir de uma descrição geral sobre aspectos ontológicos e epistemológicos que estão na base do raciocínio desenvolvido no trabalho, serão descritos os principais aspectos que constituem método fenomenográfico. Em seguida, são abordados os procedimentos realizados para a coleta de dados e, por fim, será feita uma breve discussão sobre as limitações do método.

\section{1.}

Aspectos epistemológicos e ontológicos

O presente estudo, a partir da maneira pela qual concebe realidade (ontologia) e conhecimento (epistemologia), se inscreve no paradigma interpretativista (GREEN, 2005; BURRELL e MORGAN,1979). No interpretativismo, segundo Morgan (2005), parte-se de uma visão de mundo baseada na ideia de que a experiência social não existe concretamente, por si mesma, a não ser pela interpretação subjetiva dos indivíduos. Busca-se, portanto, compreender a sociedade a partir do ponto de vista de quem protagoniza a ação, e não do observador externo. Para o autor, "o teórico social interpretativista tenta compreender o processo pelo qual as múltiplas realidades compartilhadas surgem, se sustentam e se modificam". Morgan (2005) afirma ainda que, segundo o paradigma interpretativista, a própria ciência é concebida como resultado de uma rede de jogos de linguagem, cujas regras e conceitos implícitos são determinados subjetivamente por seus praticantes.

Esta abordagem faz um contraponto às tradicionais premissas ontológica e epistemológica do paradigma funcionalista. Para Vergara e Caldas (2005), o ponto central do paradigma interpretativo está na crítica ao objetivismo característico das escolas dos funcionalistas. Ao estudar as práticas de trabalho, Sandberg (2000) explica que o objetivismo epistemológico em que o paradigma funcionalista se baseia é dualista. Trabalhador e trabalho são entendidos como entidades separadas. Nos estudos 
funcionalistas, portanto, as atividades de um trabalho são analisadas de maneira independente em relação ao trabalhador que as executa.

O presente estudo, ao contrário, entende que os atributos usados para a realização de um trabalho efetivo são sempre situacionais e dependentes do contexto em que estão inseridos. Nesse sentido, a posição adotada aqui está baseada na noção de que a realidade não é nem singular, nem fixa, mas múltipla. As realidades, no plural, são intepretações construídas como consequência das interações práticas das pessoas com o mundo (GREEN, 2005).

\section{2.}

\section{Tipo de pesquisa}

Tendo em vista o objetivo de, a partir de um paradigma interpretativista, compreender as maneiras pelas quais um fenômeno é experimentado na prática, optouse por fazer uma pesquisa do tipo qualitativa.

Creswell (2010) descreve a pesquisa qualitativa como sendo justamente aquela em que o pesquisador tenta estabelecer o significado de um fenômeno a partir do ponto de vista dos participantes. O autor prossegue, afirmando que, para isso, é necessário identificar um grupo que compartilhe o fenômeno que é objeto da pesquisa e, em seguida, estudar os padrões que este grupo apresenta. Os procedimentos qualitativos abrangem diversas abordagens de investigação. Em comum, têm o fato de se estruturarem em passos únicos de análise, e se basearem em dados de texto e imagem. Assim, ainda segundo Creswell (2010), as estratégias de coleta, análise e comunicação dos dados variam de acordo com as disciplinas específicas de onde se originam seus respectivos estudos.

Particularmente, a disciplina em que o presente estudo se inscreve está associada à teoria da prática (FELDMAN e ORLIKOWSKI, 2011). Nesse sentido, parte da premissa filosófica de que a realidade social deve ser explicada pelo que é vivenciado, baseia sua visão teórica nas atividades (ao invés das estruturas), e define o objeto de estudo reconhecendo a centralidade das ações dos indivíduos nas dinâmicas organizacionais. Para realizar essa abordagem, o método qualitativo escolhido foi a fenomenografia. 


\section{3.}

\section{Abordagem da pesquisa fenomenográfica}

A fenomenografia é um dos métodos de abordagem qualitativa. Como nos mostra Akerlind (2005), a fenomenografia nasceu na área de educação. Sua origem remonta ao início dos anos oitenta, a partir principalmente da obra de Marton (1981) e seus pares, tendo alcançado mais popularidade nas últimas décadas. Seu pressuposto básico está na ideia de que todo fenômeno pode ser compreendido qualitativamente por um número limitado de diferentes maneiras (MARTON, 1986). Identificar e analisar essas maneiras é o objeto de estudo da fenomenografia.

Marton (1986) sugere ainda que essa busca por capturar as maneiras pelas quais um fenômeno é percebido implica em uma postura diferente do pesquisador. Ele deixa de se concentrar no fenômeno para se concentrar nas diferentes percepções acerca dele. Em linhas gerais, segundo Akerlind (2005), o que está na base desse método é a busca pelo significado de determinado fenômeno a partir da percepção de quem o vivencia. Mais especificamente, o pesquisador busca compreender as variações desses significados existentes e a relação estrutural entre cada um deles.

Cabe destacar ainda outros aspectos relevantes acerca do método fenomenográfico abordados por Marton (1986). Em primeiro lugar, ele afirma que o pesquisador não está investigando aspectos psicológicos, relacionados à maneira de pensar, seu foco é o conteúdo do que é pensado. Ainda segundo o autor, é importante notar que a abordagem fenomenográfica não vai resultar em declarações sobre o fenômeno como ele é, mas sobre como as pessoas percebem o referido fenômeno. São de interesse da fenomenografia até mesmo percepções que por algum outro critério científico poderiam ser consideradas equivocadas.

Este foco que se desloca do fenômeno em direção às percepções existentes em relação a ele é o que se chama de "perspectiva de segunda ordem" (MARTON, 1986; TRIGWELL, 2000). Compreender diretamente o fenômeno ou as estruturas de pensamento utilizadas para entendê-lo seria fazer uma análise de primeira ordem. Como já visto, no âmbito da fenomenografia, a proposta é diferente. O pesquisador quer compreender "indiretamente" as maneiras pelas quais os indivíduos - e não ele próprio - vivenciam e percebem um fenômeno. Espera-se, portanto, que haja diferentes 
maneiras qualitativas pelas quais esse fenômeno é experimentado, e que essas maneiras estejam relacionadas entre si (TRIGWELL, 2000). A descrição decorrente do método fenomenográfico é, portanto, "relacional, experimental, orientada ao conteúdo e qualitativa" (MARTON, 1986).

Assim, para que seja possível obter tais perspectivas de segunda ordem, o principal método de coleta de dados da fenomenografia são as entrevistas semiestruturadas (BOWDEN e WALSH, 2000; MARTON, 1986). Segundo Creswell (2010), as entrevistas semiestruturadas envolvem poucas perguntas, geralmente abertas, e que pretendem extrair visões e opiniões dos participantes. Em relação às entrevistas dentro do âmbito da fenomenografia, Akerlind (2005) enfatiza que se está à procura de significados subjacentes e atitudes intencionais em relação ao fenômeno investigado. Para fazer isso, sugere a autora, o método mais comum é a exploração de exemplos concretos sobre a relação do entrevistado com o fenômeno.

Outro ponto importante diz respeito ao tipo das perguntas feitas nos processos de entrevista. Como o foco é explorar o modo pelo qual o entrevistado está pensando ou experimentando o fenômeno, o pesquisador não pode se ater apenas a questões do tipo “o que", devendo levar as perguntas sempre que possível ao estágio do "por que" (AKERLIND, 2005). Sandberg (2000) sugere que a entrevista pode ter algumas poucas perguntas centrais, focadas no objeto em si do estudo, e que são seguidas por perguntas de acompanhamento. A função de tais perguntas de acompanhamento é detalhar os significados de alguns conceitos utilizados nas respostas, explorar os sentimentos do entrevistado em relação aos fenômenos descritos e explorar exemplos.

\section{4.}

\section{A construção do espaço de resultados}

Marton (1986) e Akerlind (2005) mostram que não é possível delimitar de maneira minuciosa e restrita um conjunto de técnicas para o desenvolvimento de uma pesquisa fenomenográfica. No entanto, algumas etapas gerais são comuns e podem ser identificadas claramente. Encerradas as entrevistas, todo o material é transcrito e, em seguida, lido e relido inúmeras vezes no processo de análise dos resultados (MARTON, 1986; AKERLIND 2005; TRIGWELL, 2000; MARTON e PONG, 2005). 
Akerlind (2005) mostra que as técnicas de leitura das transcrições em busca das variações de concepções sobre do fenômeno podem ser significativamente diferentes entre si. Alguns autores optam pela separação inicial de trechos emblemáticos, enquanto outros argumentam que uma frase nunca deve ser retirada de contexto.

Outra discussão apresentada por Akerlind (2005) diz respeito à possibilidade de se contar com a colaboração de outros pesquisadores ao longo das análises, e ao fato de que esse procedimento pode impactar na qualidade dos resultados. A autora aponta ainda o desafio de se estruturar, dentre as inúmeras maneiras possíveis, aquela pela qual os pesquisadores procurarão enfrentar o desafio de lidar com todos os aspectos relevantes que podem surgir ao longo de cerca de vinte entrevistas diferentes.

Como resultado do trabalho de análise do conteúdo obtido nessas entrevistas de campo, o pesquisador desenvolve um sistema de classificação de todos os modos qualitativamente diferentes de experimentar o fenômeno que foram encontrados. São as categorias descritivas (AKERLIND, 2005; BOWDEN e WALSH, 2000; MARTON, 1981).

\subsection{1.}

Categorias descritivas

O objetivo do método fenomenográfico é capturar as variações de significado, ou as diferentes concepções que as pessoas fazem a respeito de um mesmo fenômeno (AKERLIND, 2005; MARTON e BOOTH, 1997; MARTON, 1981). Portanto, tornase necessário classificar e nomear cada uma das concepções encontradas. Akerlind (2005) explica que se convencionou usar o termo categorias descritivas como forma de distingui-las das categorias empiricamente utilizadas nas descrições livres levantas no campo de pesquisa.

Assim, cada concepção identificada ou agrupada do conjunto de percepções listadas constitui uma categoria descritiva. O método fenomenográfico preconiza ainda que essas diferentes concepções tipicamente apresentam uma relação hierárquica entre si (AKERLIND, 2005; MARTON e BOOTH, 1997). Isso significa que as categorias descritivas devem ser organizadas desde a mais simples ou restrita até a mais ampla ou complexa. É o que Marton e Booth (1997) denominam de “increasing complexity”. O 
método fenomenográfico pressupõe, portanto, que cada concepção acerca de um fenômeno estará contida dentro da concepção imediatamente posterior.

Por fim, para Marton e Booth (1997), há alguns aspectos importantes que devem ser observados em relação às categorias descritivas: a) cada categoria precisa revelar algum aspecto distinto na maneira de conceber o fenômeno; b) as categorias encontradas devem ser relacionadas entre si, seja por meio da hierarquia ou da inclusão; c) O número de categorias deve ser reduzido ao mínimo possível.

Para que seja possível identificar, classificar e diferenciar as categorias é importante determinar os elementos que a constituem, são as aqui chamadas dimensões explicativas.

\subsection{2.}

\section{Dimensões explicativas}

As "dimensões de variação" (MARTON e BOOTH, 1997) ou "relações estruturais" (AKERLIND, 2005) são os aspectos do fenômeno que têm a função de explicar, estruturar e relacionar entre si cada uma das categorias descritivas encontradas. São, como denomina Sandberg (2000), os "atributos chave" de cada concepção. Em outras palavras, essas "dimensões explicativas" (FIGUEIRA, 2016) representam as variáveis que ligam, correlacionam entre si e explicam as maneiras pelas quais cada categoria descritiva se diferencia das demais.

Nesse sentido, o método fenomenográfico convencionou organizar os achados em uma matriz em que um eixo traz as categorias descritivas e o outro as detalha a partir das dimensões explicativas. É o que se denomina espaço de resultados (Outcome Space).

\subsection{3.}

\section{Espaço de resultados.}

O espaço de resultados é um quadro, ou uma matriz, que apresenta a relação estrutural entre as categorias descritivas e as dimensões explicativas. Para Akerlind 
(2005), idealmente o espaço de resultados deve representar toda a gama de formas possíveis de experimentar o fenômeno em questão, considerando o momento em que o estudo é feito e a população representada coletivamente pelo grupo de amostra.

Bowden e Walsh (2000) apresentam uma interpretação ainda mais significativa sobre o papel do espaço de resultados. Para ele, o espaço de resultados é sinônimo do próprio fenômeno em si. Em outras palavras, Bowden e Walsh (2000) consideram que as maneiras de se experimentar um fenômeno não são "sombras subjetivas desse fenômeno", mas partes de um todo único, o fenômeno em si, e que é ao mesmo tempo subjetivo e objetivo.

Para Sandberg (2000), por fim, o espaço de resultados torna possível demonstrar conjuntamente tanto a constituição estrutural dos modos de conceber o fenômeno, quanto as maneiras pelas quais eles variam entre si.

\section{5. Justificativa da abordagem de pesquisa}

Uma vez que o principal objetivo do presente estudo é compreender o que constitui competência no âmbito das rotinas de programação da produção, sempre do ponto de vista dos programadores, optou-se por uma visão centrada na prática, com uma abordagem interpretativa, e realizada a partir do método fenomenográfico. Tal escolha se baseia na visão inaugurada em Sandberg (2000) - e posteriormente aprofundada por outros pesquisadores - que sugere que as abordagens funcionalistas não são as mais indicadas para estudar as competências. $\mathrm{O}$ motivo desse entendimento é que a racionalidade inerente a elas acaba por negligenciar a natureza contextual desse tipo de fenômeno.

Ao contrário das abordagens racionalistas, portanto, a proposta desse trabalho é buscar o entendimento sobre o que constitui a competência de programação da produção levando em consideração, principalmente, o significado que a atividade tem para aqueles que a realizam. Em outras palavras, a proposta é investigar o que um programador da produção entende como sendo uma realização competente de suas rotinas. Pretende-se fazê-lo tomando por base os relatos destes programadores a partir de sua experiência. 
Assim, o método fenomenográfico parece ser a abordagem ideal para realizar esse tipo de empreitada, uma vez que a sua proposta também é investigar de forma qualitativa as diferentes maneiras pelas quais as pessoas entendem um fenômeno em particular. Na fenomenografia, como visto, tais concepções distintas são agrupadas em categorias descritivas e, em seguida, correlacionadas logicamente em um espaço de resultado (MARTON e PONG, 2005). Esse espaço de resultados corresponderá a gama de respostas encontradas para a pergunta de pesquisa. E representará também os entendimentos possíveis do fenômeno investigado (a competência nas rotinas de programação da produção) à luz dos relatos de seus praticantes.

\section{6.}

\section{Coleta dos Dados}

Os dados coletados nesse estudo foram obtidos por meio de entrevistas semiestruturadas com profissionais de diferentes posições (gerentes, programadores e analistas) dentro das suas respectivas rotinas organizacionais de programação da produção. Os entrevistados relataram seus entendimentos sobre o que consideravam melhores práticas e sobre o caracterizava um programador de produção competente. Perguntas centrais foram acrescidas de perguntas de acompanhamento que buscavam detalhar as percepções, capturar as emoções envolvidas e explorar exemplos.

\subsection{1.} Variedade dos sujeitos

Os sujeitos entrevistados foram os responsáveis diretos pelas atividades de planejamento e programação da produção das empresas, em diferentes níveis, geralmente com cargos descritos como programadores de produção, analistas e gerentes de PCP. Assim, no intuito de construir um campo em que esteja garantida uma variedade de sujeitos, definiram-se alguns critérios de diferenciação. São eles: o porte das empresas, o setor de atuação, tempo de experiência profissional e a formação acadêmica. 
O primeiro deles, o porte das empresas, foi fundamental porque o tamanho da organização industrial tem influência direta em três aspectos importantes para a análise. A saber: a) o nível de organização e maturidade das informações disponíveis para o planejador; b) o aparato tecnológico e informacional disponível para o ato de planejar; e c) o grau de especialização das funções dentro da rotina. O segundo critério de diferenciação em que foi importante obter variedade diz respeito aos setores competitivos de atuação das empresas, o que reflete em suas naturezas de produto e processo. O setor está diretamente relacionado às restrições e aos objetivos que são impostos aos programadores. Seus graus de complexidade podem variar amplamente, determinando diferentes modos particulares de trabalhar e conceber o trabalho. Em uma terceira frente, foi importante perceber eventuais variações nas concepções de acordo com o tempo de experiência dos profissionais. Se, por um lado, é possível supor que profissionais mais experientes detenham uma visão global das rotinas, também pode esperar que em alguns casos sejam mais resistentes ao uso de tecnologias modernas. É preciso verificar se tais intuições são realmente fundamentadas na realidade prática. Por fim, e de maneira complementar, foi importante garantir variedade também de formação escolar e acadêmica dos envolvidos, evitando um eventual viés de origem. 


\begin{tabular}{|c|c|c|c|c|c|c|c|c|c|}
\hline $\begin{array}{l}\stackrel{\times}{\times} \\
\stackrel{\infty}{\infty}\end{array}$ & 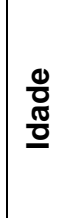 & Formação Acadêmica & Cargo Atual & 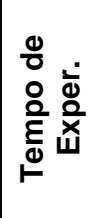 & 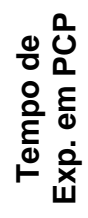 & $\begin{array}{c}\text { Porte da } \\
\text { empresa (No } \\
\text { de } \\
\text { funcionários) }\end{array}$ & $\begin{array}{c}\text { Porte da empresa } \\
\text { (Receita Bruta em } \\
\text { Milhões) }\end{array}$ & Empresa & Setor de atuação \\
\hline M & 54 & Eng. de Produção & Supervisor de PCP & 25 & 15 & Mais de 500 & do $R \$ 90$ a $R \$ 300$ & Todeschini & Moveleiro \\
\hline $\mathrm{M}$ & 36 & Matemática (incomp.) & Administrativo PCP & 12 & 4 & de 20 a 99 & de $R \$ 2,4$ a $R \$ 16$ & Show Móveis & Moveleiro \\
\hline $\mathrm{F}$ & 27 & Administração & Supervisora do PCP & 9 & 6 & de 100 a 499 & de $\mathrm{R} \$ 16$ a $\mathrm{R} \$ 90$ & - & Equip. Industriais \\
\hline $\mathrm{M}$ & 40 & Eng. de Prod. Mecânica & Gerente de PCP & 20 & 12 & de 20 a 99 & Mais de $\mathrm{R} \$ 300$ & CBA & Metalurgia \\
\hline $\mathrm{M}$ & 36 & Tec. Eletrônica & Analista de processo & 16 & 5 & de 100 a 499 & - & Arris & Engenharia \\
\hline $\mathrm{F}$ & 48 & Psicologia & Gerente de PCP & 30 & 20 & de 100 a 499 & Mais de $R \$ 300$ & Agfa & Filme/chapa de alum. \\
\hline M & 24 & Eng. Mecânica & Analista de Planej. Pleno & 7 & 4 & Mais de 500 & Mais de $\mathrm{R} \$ 300$ & Comil Ônibus & Metalmecânico \\
\hline M & 29 & Tec. Logística e Prod. & Analista de Planejamento & 11 & 9 & Mais de 500 & Mais de $\mathrm{R} \$ 300$ & - & Automotivo \\
\hline $\mathrm{M}$ & 28 & Eng. de Produção & Analista de PPCP & 9 & 4 & Mais de 500 & Mais de $R \$ 300$ & CBA & Metalurgia \\
\hline $\mathrm{F}$ & 42 & Eng. Civil & Gerente Administrativa & 15 & 3 & de 20 a 99 & de $R \$ 2,4$ a $R \$ 16$ & - & Moveleiro \\
\hline $\mathrm{M}$ & 47 & Eng. Mecânica & Gerente de PCP & 25 & 19 & de 100 a 499 & do $R \$ 90$ a $R \$ 300$ & Têxtil Farbe & TÊXTIL \\
\hline M & 47 & Administração & Ger. de Suprim. e Planej. & 10 & 4 & de 100 a 499 & Menos de $\mathrm{R} \$ 2,4$ & - & Equip. eletrônicos \\
\hline $\mathrm{F}$ & 48 & Gestão de PME & Programadora de Prod. & 25 & 18 & de 100 a 499 & Mais de $\mathrm{R} \$ 300$ & Agfa & Filme/chapa de alum. \\
\hline M & 31 & Administração & Supervisor de PCP & 6 & 2 & de 100 a 499 & de $R \$ 2,4$ a $R \$ 16$ & - & Equip. eletrônicos \\
\hline M & 34 & Administração & Coordenador de PCP & 19 & 12 & Mais de 500 & Mais de $R \$ 300$ & CBA & Metalurgia \\
\hline
\end{tabular}

Quadro 1. Caracterização dos sujeitos que participaram do estudo. Elaborado pelo autor. 


\subsection{1.}

Formulação do roteiro de entrevistas

A condução das entrevistas semiestruturadas foi feita com base em um roteiro (Apêndice 1) composto por duas perguntas centrais e algumas questões de acompanhamento. As perguntas centrais tiveram foco direto nas rotinas organizacionais de planejamento e programação da produção, e também nas suas respectivas concepções de competência. A função das questões de acompanhamento foi aprofundar as respostas e descrever exemplos a partir das práticas. Assim, inspirado nos trabalhos de Figueira (2016) e Sandberg (2000), o roteiro foi divido em quatro partes: a) questão introdutória; b) perguntas centrais; c) questões de desenvolvimento das experiências; e d) perguntas acessórias.

O objetivo da questão introdutória - "para contextualizar, você poderia me falar qual é o porte da empresa, o setor de atuação, seu tempo de experiência profissional e sua a formação acadêmica" - foi o de fazer o levantamento demográfico de cada entrevistado, de forma a situá-lo dentro de seu contexto organizacional. Nesse sentido, teve papel importante para caracterização do perfil de cada entrevistado selecionado e permitiu a validação da variedade de sujeitos que havia sido estabelecida no começo do estudo. Complementarmente, as questões introdutórias serviram para dar início à conversa propriamente dita, sintonizando o diálogo entre entrevistador e entrevistado.

Nas entrevistas, após as questões introdutórias, era formulada a primeira questão central do roteiro: “o que significa programação da produção para você?”. O objetivo dessa pergunta foi capturar a concepção do entrevistado a respeito das rotinas organizacionais que foram objeto deste estudo. A partir dela, o entrevistado descrevia o aspecto ostensivo das rotinas e era convocado a formular inicialmente a sua concepção sobre as características essenciais das referidas rotinas organizacionais, incluindo as atividades requeridas, as relações de interdependência e os artefatos envolvidos. Para aprofundar e detalhar essa concepção inicial, o roteiro da pesquisa continha as questões de desenvolvimento da experiência. Com esse recurso, estava prevista a possibilidade de explorar dificuldades e facilidades encontradas, além de 
obter descrições concretas de exemplos situacionais de casos bem-sucedidos ou malsucedidos.

Em seguida, o roteiro foi construído de forma que, uma vez que a concepção sobre o significado das rotinas organizacionais de planejamento e programação dos entrevistados estivesse consolidada, o entrevistador deveria avançar para a segunda pergunta central: “O que é para você um programador de produção competente?”. Essa pergunta teve o objetivo de avançar na concepção inicial do entrevistado sobre o significado das rotinas, levando-o a formular de maneira direta uma resposta à pergunta de pesquisa, isto é, a construir sua concepção sobre a competência nessas rotinas. Assim, como descrito em relação à primeira pergunta central, o roteiro previu questões de desenvolvimento e também questões acessórias de aprofundamento e exemplificação.

Considerando este movimento iterativo das entrevistas, cabe ressaltar que a função das referidas questões de desenvolvimento das experiências foi a de esmiuçar cada descrição da relação dos sujeitos com o fenômeno em si. Acompanhadas das questões acessórias, seu objetivo foi esclarecer as concepções formuladas, validar os entendimentos iniciais, aprofundar as descrições, e ainda detalhar os aspectos da prática das rotinas em que as definições de competência podiam ser verificadas. Para cumprir estes objetivos, as questões de desenvolvimento das experiências se valeram de dois recursos principais. O primeiro deles consistiu em pedir aos entrevistados que descrevessem as dificuldades com as quais costumam se confrontar na realização de suas rotinas organizacionais, e também as facilidades que encontram cotidianamente. $\mathrm{O}$ intuito específico dessas perguntas foi levar o entrevistado a refletir sobre alguns aspectos chave do fenômeno, tais como as relações de dependência com outros atores, os artefatos de que dispunha, e as dissonâncias entre os aspectos ostensivo e performativo. O outro recurso foi a solicitação da descrição de situações que tivessem sido avaliadas como bem ou malsucedidas. Nesses momentos, a proposta era levar entrevistado a trazer aspectos da prática das rotinas para o seu discurso, de modo a consolidar as suas concepções iniciais.

As perguntas acessórias - "Por que (isso) ocorreu?", “Como você superou (isso)?", e "Como (isso) te ajudou?", dentre outras - foram recursos complementares 
para que o entrevistador pudesse manter o diálogo ativo e focado no objetivo de pesquisa proposto. Por fim, foi previsto no roteiro também um discurso de agradecimento aos entrevistados pela disponibilização do tempo e abertura de espaço para a entrevista.

\subsection{2.}

\section{Condução das entrevistas}

No total, foram realizadas 20 entrevistas, todas via Skype, em chamadas de vídeo. Elas ocorreram ao longo do ano de 2016, entre os meses de maio e dezembro. Todas as entrevistas foram gravadas e totalizaram um registro de 13 horas e quarenta e nove minutos, sendo que a menor entrevista levou 33 minutos e a maior 48 minutos. Todos os convites aos participantes foram feitos via e-mail. O número de convites enviados foi cerca de $40 \%$ maior do que o número de entrevistas efetivamente realizadas.

A maioria das entrevistas ocorreu nas datas agendadas, houve naturalmente alguns casos de reagendamento, e em algumas poucas situações particulares em que o pesquisador precisou substituir os convidados, uma vez que não se conseguiu, em tempo hábil, chegar a uma nova data de consenso. Foi possível notar alguma resistência inicial por parte de alguns entrevistados pelo fato de as entrevistas serem todas por vídeo. Em virtude das dificuldades naturais de se conseguir pessoas habilitadas e disponíveis às entrevistas, vale dizer que parte significativa das participações derivou da rede de relacionamentos profissionais do pesquisador.

Seguindo as etapas previstas no roteiro de entrevistas, após os cumprimentos, as breves considerações iniciais e as questões introdutórias, a primeira pergunta central convocava o entrevistado a formular sua concepção inicial acerca do significado de suas rotinas. Em geral, e não necessariamente nessa ordem, eles descreviam a natureza da função, os objetivos do trabalho e as atividades principais. Dependendo do grau de profundidade e detalhamento dessa resposta, o pesquisador recorria às questões de desenvolvimento da experiência para aprofundá-la. Muitas vezes o entrevistado tecia introdutoriamente uma lista de aspectos iniciais. Nesses casos, o pesquisador tomava notas de tais aspectos e conduzia as questões de desenvolvimento ou acessórias de 
forma a esmiuçar as concepções em torno de cada um dos aspectos inicialmente comentados.

Cabe destacar que o pesquisador procurou sempre deixar que as respostas fluíssem a partir das perguntas, evitando fazer intervenções. Nesse sentido, é importante frisar que as questões de desenvolvimento e as questões acessórias só foram utilizadas quando necessário e como forma de manter o participante focado nos conteúdos de interesse do estudo.

\section{7.}

\section{Tratamento e análise dos dados emergentes do campo}

\subsection{1}

\section{Tratamento dados}

As transcrições dos relatos registrados nas 20 entrevistas gravadas totalizaram 224 páginas. Conforme preconiza o método fenomenográfico, o primeiro passo da análise dessas transcrições consistiu no trabalho de descontextualização de seu conteúdo em relação aos sujeitos entrevistados. Para isso, foi retirada qualquer associação nominal das entrevistas e elas foram embaralhadas. A partir daí foi possível fazer as leituras sem que o conteúdo das entrevistas pudesse ser relacionado à pessoa que o proferiu. Dessa forma, o foco das análises pôde ser concentrar exclusivamente no conteúdo das falas, sem se deixar influenciar por conhecimentos prévios sobre a empresa ou por diferentes níveis de empatia em relação aos entrevistados.

Conforme mostra Akerlind (2005), existem na fenomenografia diferentes abordagens possíveis para se fazer a análise dos dados e formar as categorias descritivas. De forma geral, elas se dividem entre dois procedimentos distintos de análise. Em um deles, os pesquisadores separam de cada transcrição pequenos trechos que digam respeito especifico ao objeto de estudo. Posteriormente, eles agrupam estes trechos em rodadas iterativas de releitura, até formar as categorias descritivas e identificar as dimensões explicativas. Ainda segundo Akerlind (2005), o outro procedimento parte do princípio de que os trechos nunca devem ser separados de seus relatos como um todo. $\mathrm{O}$ contexto geral de um relato, para os pesquisadores dessa 
abordagem, seria um pano de fundo necessário para que os pesquisadores sejam capazes de significar o conteúdo das falas presentes nos relatos (AKERLIND, 2005). O presente estudo optou pela abordagem que analisa os transcritos sempre dentro dos contextos dos relatos como um todo. A vantagem dessa opção, segundo Akerlind (2005) é permitir que toda a transcrição seja compreendida e tratada como um conjunto de significados inter-relacionados, e que são melhor compreendidos justamente nessa relação.

\subsection{2}

\section{Análise dados}

A condução da análise dos dados tomou como base alguns estudos de referência em relação ao uso do método fenomenográfico, tanto em sentido amplo quanto particularmente na área de organizações. Especificamente, os procedimentos se fundamentaram nos trabalhos de Akerlind (2005), Bowden (2000), Sandberg (2000), Marton e Booth (1997) e Marton (1986).

O período de análise durou cerca de dois meses. A primeira etapa consistiu na leitura integral e consecutiva de todas as transcrições. Cabe lembrar que desde esse primeiro momento os relatos já estavam desassociados dos entrevistados. O objetivo desse trabalho foi fazer uma aproximação inicial do pesquisador com os dados, possibilitando uma visão abrangente e completa das informações coletadas. Nesse momento, ideias preliminares acerca das concepções começaram a ser formuladas. É importante frisar, em que pesem as limitações inerentes, que esse processo foi todo conduzido com a preocupação do pesquisador em se manter o mais isento possível em relação aos dados. O que significa que o pesquisador procurou não deixar que as suas visões prévias acerca do tema induzissem as considerações que construía a partir dos relatos. Sandberg (2000) sugere alguns critérios de confiabilidade para a formulação das concepções: a) o pesquisador deve evitar o seu conhecimento prévio sobre o tema, verificando continuamente se as interpretações estão fundamentadas nas descrições dos relatos, b) todas as declarações devem ser tratadas como sendo igualmente importantes para as interpretações; e c) deve-se validar a interpretação de cada concepção, fazendo um cruzamento com as demais concepções. 
A segunda etapa consistiu em uma nova releitura consecutiva de todas as 20 entrevistas, porém agora procurando separar e agrupar cada um dos relatos com base em semelhanças gerais. Ao final da leitura do primeiro deles, elaborou-se uma intepretação geral de seu conteúdo e, toda vez que outro relato parecia se assemelhar a essa interpretação geral, ele era reunido em conjunto com o primeiro. Ao passo que, quando um relato seguinte divergia do anterior, ele era encaminhado a outro grupo ou fundava um grupo novo, caso nenhum dos existentes se adequasse a seu perfil geral. Com isso, os agrupamentos preliminares foram formados. Para Marton e Booth (1997), nessa etapa, o autor começa a verificar em linhas gerais o que os sujeitos respondem sobre o problema de pesquisa.

Assim, a etapa seguinte consistiu na leitura dos relatos grupo a grupo. O objetivo foi verificar se os agrupamentos prévios eram capazes de configurar uma concepção clara e unívoca sobre a constituição da competência nas rotinas organizacionais de planejamento e programação da produção. Ao longo dessas leituras, alguns relatos migraram de um grupo e a outro. Nesse processo, dois grupos iniciais acabaram se tornando um só. É importante frisar também que, ao longo dessa terceira leitura, os principais trechos representativos que assinalavam cada relato dentro de um determinado grupo foram sendo sinalizados. Ao se chegar a uma nova configuração de grupos, o processo de releitura e reagrupamento voltava para iniciar um novo ciclo de releitura e validação. A diferença é que desta vez a leitura já priorizava os trechos sinalizados. Este ciclo se repetiu cerca de três ou quatro vezes até que três grupos principais, e que pareceram configurar três categorias descritivas, ainda não nomeadas, se estabilizaram.

O passo seguinte foi fazer uma leitura integral dos relatos, novamente grupo a grupo, mantendo uma atenção especial nos trechos sinalizados e agora sinalizando outros trechos. Ao longo desse processo, alguns extratos foram destacados e denominados livremente em uma tentativa preliminar e individual de capturar as dimensões. Quando uma dimensão parecia se repetir, ela ganhava o mesmo nome. Quando um trecho parecia jogar nova luz sobre uma dimensão preexistente, ela era renomeada. Cabe frisar que desde o início da sinalização dos trechos, a ideia metodológica já era destacá-los porque possuíam características tais que o tornavam 
capazes de justificar o agrupamento. Por essa razão, puderam ser considerados como indicativos preliminares das potenciais dimensões explicativas.

O passo seguinte foi um novo processo de releitura com o intuito de compreender a natureza desses trechos demarcados e seus sentidos gerais no processo de delimitação de cada categoria descritiva. Nesse momento, foi possível, então, identificar aqueles trechos sinalizados que podiam ser estruturados em algumas dimensões e ajudavam a explicar as categorias e a relacioná-las entre si.

A próxima etapa consistiu na realização de testes de alocação dos extratos sinalizados. O objetivo dessa etapa foi consolidar os aspectos que configuram as dimensões explicativas. Nesse processo, as dimensões iniciais foram agrupadas e um número menor e mais sólido de dimensões. Em seguida, foi feita uma releitura integral dos relatos, grupo a grupo, com foco na validação da experiência comum de todos os relatos do mesmo grupo e refeito o processo em relação a cada dimensão.

Por fim, vale dizer que a relação hierárquica entre cada categoria descritiva identificada ficou muito evidente desde o início. Tal hierarquia, conforme preconiza o método (AKERLIND, 2005, MARTON, 1986) se baseia tanto na abrangência das categorias quanto no nível de complexidade delas. Ao longo da redação do capítulo de análise e resultados, o presente estudo apresenta alguns desses trechos que foram sinalizados durante $\mathrm{o}$ processo de análise, dando prioridade àqueles mais representativos das concepções em relação ao fenômeno estudado.

\section{8.}

\section{Limitações da abordagem de pesquisa}

Assim como os demais métodos de pesquisa, pode-se dizer que a abordagem fenomenográfica apresenta algumas limitações decorrentes da natureza de suas perspectivas e métodos. Bowden e Walsh (2000) apontam o fato de que na fenomenografia a análise se restringe ao que está explicitado no texto (transcrito da fala). Esse procedimento faz com que alguns elementos possam ficar à sombra. Isto é, aspectos da experiência real em relação ao fenômeno podem ser transferidos para o discurso de forma ambígua, indefinida; podem não ser entendidos ou até mesmo passar despercebidos por não terem sido abordados com uma ênfase condizente. O roteiro das 
entrevistas e os cruzamentos das informações sistematizadas ao longo das diversas etapas de análise são formas de lidar com essas limitações e minimizar seu impacto.

Marton e Booth (1997), por sua vez, apontam para o fato de que o grau máximo de variação entre as diferentes concepções do fenômeno é, em última instância, individual. O processo de construção das categorias descritivas, no entanto, trata das variações de concepção em um nível coletivo, o que faz com que algumas particularidades possam ser suprimidas em seu decorrer.

Bowden e Walsh (2000) sugerem ainda que é comum que a existência de limitações no que concerne às amostras obtidas, especialmente em se considerando que alguns critérios precisam ser estabelecidos exclusivamente tornar a pesquisa manejável, como, por exemplo, no âmbito de uma dissertação de mestrado. No caso do presente estudo, esse aspecto aparece no fato de que o grupo de entrevistados faz parte da rede ampla de relacionamentos profissionais do pesquisador, o que poderia incorrer em algum viés de origem. Para lidar com esse fato, o presente estudo procurou se valer de uma construção cuidadosa da amostra que considerasse uma variação de sujeitos apropriada, conforme indicado no tópico 3.6.1. 


\section{4 Resultados encontrados}

Neste capítulo serão apresentados, discutidos e exemplificados os resultados encontrados nas entrevistas de campo, considerando-se a pergunta principal de pesquisa, os objetivos específicos e o arcabouço teórico que baliza o estudo. Após uma breve discussão introdutória, o capítulo está divido em cinco seções. Na primeira delas é apresentado um panorama geral das categorias descritivas e das dimensões explicativas. Isto é, são listadas as concepções de competência que emergiriam dos relatos e detalhadas as dimensões que estruturam e relacionam tais concepções. Em seguida, há uma seção de apresentação, detalhamento e discussão para cada uma das três categorias descritivas identificadas. Ao final, na última seção, os achados são estruturados na construção do espaço de resultados.

Próprio ao método fenomenográfico, o espaço de resultados (AKERLIND, 2005) consiste em uma organização resumida e tabular que sistematiza de forma hierárquica o objeto principal da investigação acerca do fenômeno, as chamadas categorias descritivas. Nesse sentido, mais especificamente, as categorias descritivas descritas a seguir constituirão os conjuntos encontrados de diferentes maneiras pelas quais os entrevistados experimentam e compreendem a competência na programação de produção. Note-se ainda que essas categorias descritivas, conforme preconiza o método fenomenográfico (AKERLIND, 2005; MARTON e BOOTH, 1997), indicam percepções distintas sobre o que são as rotinas de programação da produção, e como as diferentes percepções do que é e competência em sua execução se relacionam entre si. Em outras palavras, as categorias descritivas foram formadas a partir do agrupamento das diferentes maneiras pelas quais os entrevistados responderam à pergunta de pesquisa, descrevendo tanto as rotinas de planejamento e programação da produção quanto suas concepções a respeito do que constitui a competência na realização destas rotinas.

Cabe observar que a utilização das rotinas como unidade de análise para o estudo organizacional se baseia na ideia de que os padrões de ação explicam mais sobre o comportamento organizacional do que o foco exclusivo nas decisões em si ou nos 
atores envolvidos (PENTLAND e FELDMAN, 2005; PARMIGIANI e HOWARDGRENVILLE, 2011; PENTLAND e HÆREM, 2015). A teoria destaca ainda o papel da cultura organizacional como origem desse repertório de estratégias de ação, capaz de moldar os artefatos das rotinas e definir as expectativas colocadas sobre elas (BERTELS, HOWARD-GRENVILLE e PEK, 2016). A presente análise das entrevistas de campo, que será descrita a seguir, sugere que o conjunto de diferentes concepções sobre a rotina de planejamento e programação da produção corrobora e exemplifica tais prerrogativas teóricas. Particularmente, o exercício competente da função de planejamento e programação da produção, assim como as próprias práticas que foram descritas como pertencentes às rotinas organizacionais, segundo os relatos, refletem de maneira explícita e contundente a cultura das organizações em relação às operações fabris.

Além das categorias descritivas, o espaço de resultados (outcome space) é constituído pelas "dimensões explicativas", que representam aspectos chave do fenômeno e têm a função de explicar, estruturar e relacionar entre si as categorias descritivas. Ao longo do detalhamento de cada uma das categorias descritivas, portanto, serão descritas também as maneiras como cada uma dessas dimensões explicam e constituem essas diferentes concepções, tanto sobre as programação da produção propriamente ditas, quanto sobre seu exercício competente.

Note-se, por fim, que nos excertos das entrevistas apresentados ao longo deste capítulo, assim como nos diálogos do campo, foram utilizados alguns termos técnicos e profissionais que são específicos da prática dos programadores de produção. Cabe destacar que os termos são de conhecimento pleno do pesquisador e, portanto, não interferiram na análise dos resultados. No Apêndice II há um pequeno glossário que lista e descreve essas expressões.

\section{1.}

\section{As Categorias Descritivas e as Dimensões Explicativas}

O objetivo principal deste trabalho, como já detalhado no primeiro capítulo, é compreender o que constitui a competência na área de planejamento e programação da produção, tomando como base as diferentes concepções acerca do fenômeno que 
emergem da prática e da fala dos próprios programadores. Assim, ao final das etapas de coleta, tratamento e análise dos dados obtidos nas entrevistas de campo, identificouse a existência de três concepções diferentes pelas quais os programadores definem o exercício competente da função de programação da produção. Tais percepções estão diretamente relacionadas às maneiras como os programadores descrevem a natureza, a forma e o propósito de suas rotinas de programação. É o conjunto de significados encontrados, a que o método fenomenográfico denomina também de pool of meanings (BOWDEN e GREEN, 2005). As três categorias descritivas encontradas, foram: 1) Alocação de recursos e materiais; 2) Mediação entre diferentes áreas da empresa; e 3) Gestão tático-estratégica da operação.

É importante notar que há uma clara relação hierárquica entres essas categorias, estando cada uma contida dentro da categoria imediatamente posterior. Tal hierarquia diz respeito tanto à abrangência quanto à complexidade ("increasing complexity") de cada uma das concepções (MARTON e BOOTH, 1997). É um pressuposto do método fenomenográfico e que ficou muito evidente ao longo da análise de dados do presente estudo. Nas entrevistas que foram agrupadas dentro da concepção que define a competência na programação de produção como a "Alocação de recursos e materiais", por exemplo, os entrevistados se mantêm restritos a essa única noção, mesmo diante de perguntas que abrem espaço para o desenvolvimento de outros papéis e interpretações distintas de cada uma das dimensões. Nas demais concepções, esta mesma competência do programador também é sempre citada, mas as descrições já não se atêm a ela. As entrevistas que apontam para a concepção de "Mediação entre diferentes áreas" sempre mencionam esse o aspecto de "melhor alocação", tal aspecto está nitidamente incluído em sua concepção, porém ela é mais ampla. Pois, diferentemente da primeira categoria, na segunda se vê a capacidade de "Mediação" como sendo a competência essencial. Do mesmo modo, nos casos em que as descrições das entrevistas apontam para a concepção de "Gestão tático-estratégica da operação", considerada a mais ampla e complexa entre as três, tantos as capacidades de "Mediação" quanto de "Melhor alocação" estão presentes, ainda que a competência principal seja descrita de forma mais abrangente. A figura 1 ilustra, a partir modelo de 
reconfiguração do mapa de espaço de resultado proposto por Cherman e Da RochaPinto (2016), a relação hierárquica entre as categorias descritivas.

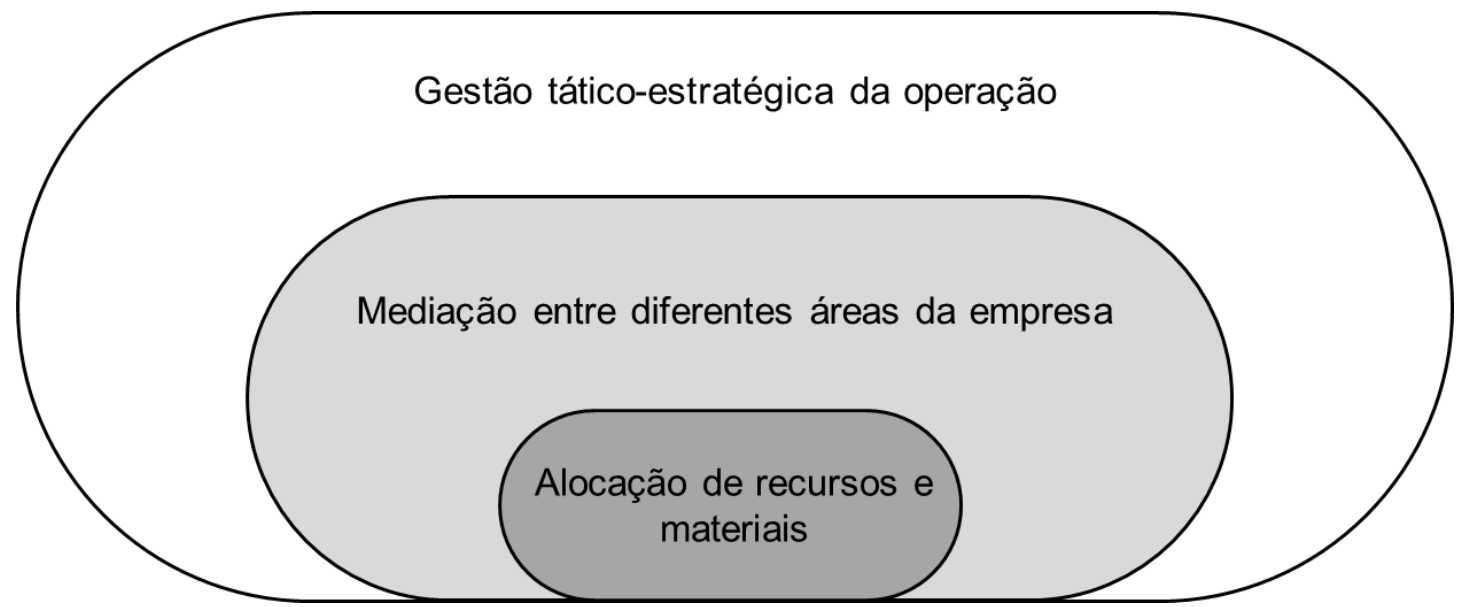

Figura 1. Hierarquia entre as categorias descritivas. Elaborado pelo autor.

Em seguida, o processo de análise dos dados obtidos nas entrevistas também possibilitou a identificação de cinco atributos da competência, que possuem papel chave para distinguir as concepções, estruturá-las e compreender a maneira como se relacionam entre si. As seis "dimensões explicativas" que emergiram das descrições e constituem o segundo eixo do espaço de resultados (ver Quadros 2 e 3) são, portanto: 1) Raciocínio lógico, 2) Conhecimento técnico (relativo ao processo produtivo), 3) Conhecimento sistêmico (relativo às outras áreas), 4) Estratégia de negociação, 5) Aspecto manifesto da rotina e 6) Envolvimento com a estratégia corporativa (relação com os objetivos estratégicos).

O Raciocínio lógico se refere às habilidades pessoais a que, segundo os entrevistados, os programadores primeiro (ou principalmente) recorrem para a execução das tarefas da rotina de planejamento programação da produção. Diz respeito ao principal aspecto ostensivo da rotina (FELDMAN e ORLIKOWSKI, 2011; PENTLAND e FELDMAN, 2005) frequentemente citado nas entrevistas. Este aspecto ostensivo é a tarefa de elaborar, geralmente via planilhas, soluções de programação que sejam "otimizadas" e "eficientes".

O raciocínio lógico foi muitas vezes listado como uma qualidade fundamental para o programador, uma vez que parte significativa do trabalho consiste em solucionar 
um problema matemático e numérico de distribuição de necessidades de produção entre as máquinas e recursos disponíveis, de forma a garantir a melhor eficiência possível. No entanto, foi possível notar que os entrevistados trabalham a ideia de raciocínio lógico com duas abordagens distintas. Na primeira delas, referem-se à habilidade para a realização de cálculos, utilizando-se de planilhas, fórmulas e softwares, com foco nos resultados, isto é, na obtenção de uma programação que propicie a melhor eficiência possível na produção. A outra abordagem do raciocínio lógico tem o foco principal nas atividades de apuração, análise e interpretação das variáveis utilizadas na conta. Os entrevistados frequentemente mencionaram que grande parte das informações requeridas por eles era dinâmica e proveniente de outros setores, o que tornava necessário ter a sua natureza bem interpretada e a sua acurácia validada.

O "conhecimento técnico" relativo ao processo produtivo, por sua vez, é a segunda dimensão explicativa identificada. Diz respeito a quanto o programador conhece sobre as etapas de produção que ele programa em suas rotinas. Esta dimensão explicativa pode englobar não só o grau de entendimento das restrições e alternativas de que a área de produção dispõe, mas também as motivações e indicadores que regem o setor produtivo em questão. Pode-se afirmar que, para os programadores, conhecer o processo produtivo significa conhecer as rotinas organizacionais de outro setor (a produção), que não o próprio. É uma competência considerada decisiva porque as rotinas organizacionais de programação afetam diretamente as rotinas organizacionais de produção, e vice-versa. Esse tipo relação de dependência mútua exemplifica significativamente o que a literatura sobre rotinas organizacionais, especialmente sob a perspectiva prática (FELDMAN e ORLIKOWSKI, 2011), classifica como as relações de interdependência entre as rotinas. Nesse sentido, conforme apontado por DEKEN $e t$ al. (2016), as relações de interdependência possuem três aspectos principais novidade, dependência e diferença (CARLILE, 2004) - e que estão intrinsecamente associados a essa dimensão explicativa do conhecimento técnico. De acordo com os relatos analisados, o conhecimento técnico influencia na aderência da programação gerada. Tal influência é consequência direta do aspecto de dependência entre as áreas, uma vez que quem determina as sequências que vão reger a produção é a programação. Nesse sentido, a programação pode propor a construção de soluções alternativas para 
a produção, quando necessário, o que reflete o aspecto da novidade dentro da relação de interpendência. Cabe destacar ainda, que este "conhecimento técnico", segundo os relatos, tem papel decisivo na confiança entre as áreas de programação e produção, assim como nos processos de comunicação e negociação entre elas. Nesse ponto, é possível vislumbrar também a dimensão da diferença. Para manejar a diferença entre as áreas, os programadores relataram recorrer justamente ao conhecimento mútuo. Desta forma, assim como aparecem nesta segunda dimensão explicativa, os aspectos de novidade, dependência e diferença também são inerentes, e de modo equivalente, à dimensão explicativa descrita a seguir.

A terceira dimensão explicativa é o "conhecimento sistêmico (de outras áreas)". Este atributo envolve não só o conhecimento das lógicas de produção, mas também das demais áreas da empresa, tais como a área comercial, a área de logística e estoques, área de qualidade, e até mesmo os demais níveis de planejamento. Abrange desde as necessidades até as práticas das demais áreas. Muitos entrevistados sugeriram que a competência nas rotinas de planejamento e programação da produção está na compreensão das métricas de desempenho dessas demais áreas. Segundo eles, tal compreensão é importante para que as referias métricas tenham peso proporcional nas decisões de programação e sejam consideradas nas atividades da rotina relativas à negociação entre as áreas. É nesse sentido que se inscreve também na teoria acerca da relação de interpendência entre áreas (DEKEN et al. 2016; CARLILE, 2004). Nas descrições levantadas no campo, este conhecimento sistêmico está relacionado ao domínio das variáveis organizacionais que, de maneira interdependente, interferem na área de programação de produção, afetando-a ao mesmo tempo em que são afetadas por elas. A relação da área de planejamento e programação da produção com as demais áreas é naturalmente menos direta e imbricada do que a sua relação com a produção em si. No entanto, para muitos programadores ouvidos, esta relação com as demais áreas ela tem uma dimensão de importância equivalente ou até superior à relação com a produção. Note-se que o mero reconhecimento dessa dimensão explicativa por parte dos entrevistados já revela indiretamente também uma percepção da centralidade da área de planejamento e programação dentro do contexto mais amplo da operação. Além disso, essa dimensão de "conhecimento sistêmico" pode ser lida como um primeiro 
indicativo da relação da programação de produção com os resultados globais da empresa. Cabe ressaltar que a dimensão explicativa de "conhecimento sistêmico" pode variar significativamente também. Desde um mero reconhecimento da importância dos pontos de interface entre as áreas, até uma visão global da empresa em que se entende a natureza do trabalho e a razão de ser de cada uma dessas demais áreas.

Considerando-se, então, esse caráter interdependente da programação de produção, a quarta dimensão explicativa está relacionada ao estratégia de negociação organizacional que é praticada pelo programador em suas interações com as demais áreas. A literatura sobre o a negociação organizacional estabelece a existência de três estratégias de negociação fundamentais (BRETT e THOMPSON, 2016; THOMPSON, WANG e GUNIA, 2010). Em uma extremidade está a chamada estratégia distributiva, em que a parte interessada (nesse caso, o programador) procura negociar o programa (principalmente com as áreas comercial e de produção) de forma a maximizar o resultado para si. Mais especificamente, isso significa maximizar os resultados dos indicadores locais pelos quais o seu próprio trabalho de programação é medido. Nesse sentido, foi possível identificar nas falas de alguns programadores que quando entravam em processos de negociação, o faziam no sentido de convencer a outra parte a aceitar um programa que fosse mais adequado aos critérios gerais que regem a sua área de planejamento e programação da produção. Essa abordagem ocorreu tanto nas negociações feitas com a produção quanto naquelas com a área comercial. Ainda segundo Thompson e Brett (2016), as outras duas estratégias de negociação consagradas são: a) a integrativa, e b) a estratégia de reciprocidade ou parceira. $\mathrm{Na}$ estratégia de negociação integrativa, o que se busca integrar são os objetivos das duas partes envolvidas na negociação (THOMPSON, WANG e GUNIA, 2010). Por exemplo, a área de programação e qualquer outra área da empresa. É uma abordagem que, no caso do planejamento e programação da produção, visa a equalizar o efeito do programa gerado a partir de uma negociação que busque a obtenção de bons resultados para os indicadores de ambas as áreas impactadas. Na prática, muitos relatos apontam para esse tipo de negociação quando descrevem rotinas organizacionais como as reunião diárias de acompanhamento. Com diferentes nomes e formatos, mas recorrentes nas entrevistas, essas reuniões são formadas por todos gerentes. Estes 
levam para debate os seus indicadores, as suas necessidades e as suas restrições. Com isso, as decisões são tomadas no consenso do coletivo. Já na estratégia de negociação classificada como reciprocidade e parceria, o foco está voltado não só para os resultados locais de cada parte, mesmo que somados ou considerados com pesos equânimes, mas para o ganho geral da solução negociada (BRETT e THOMPSON, 2016). Na interpretação sugerida aqui, os resultados e o ganho global esperado são representados pelos indicadores estratégicos da corporação que estariam em jogo. No caso específico da programação da produção, a estratégia de negociação com base na reciprocidade ou parceria se dá quando a relação cotidiana com as demais áreas é sempre mediada por indicadores globais. Na prática, esse tipo de decisão se revela na fala dos programadores quando sugerem que a competência nas rotinas de planejamento e programação da produção está relacionada à sua capacidade de liderar os processos de negociação decidindo com base nos ganhos globais para a operação.

A quinta categoria reflete qual é o aspecto da teoria sobre rotinas organizacionais que se manifesta de maneira mais explícita e recorrente na concepção dos programadores acerca da competência em sua função. Foi possível identificar um primeiro conjunto de descrições majoritariamente atrelado ao aspecto performativo das rotinas. Isto é, para estes programadores, a competência na rotina programação está majoritariamente associada ao desempenho das tarefas que lhe são atribuídas. São programadores que enxergam a competência como sendo a boa performance prática. Em outra extremidade, está o grupo de programadores em que se vê manifestado de forma mais frequente o aspecto ostensivo das rotinas. Neste caso, as concepções de competência dos programadores são pouco atreladas às práticas diárias de realização das atividades. Ao contrário, eles associam a competência ao papel teórico do cargo, ou seja, à razão de ser da função de programação segundo seu entendimento acadêmico ou organizacional. Há ainda outros programadores que, por sua vez, descreveram suas rotinas organizacionais e a competência associada a elas de uma maneira intermediária. Combinam aspectos performativos (relacionados a aspectos da prática das tarefas) e também ostensivos (que ser referem a expectativas prévias organização em relação à função de programação). 
A sexta e última dimensão explicativa, por sua vez, está relacionada ao envolvimento com a referida estratégia corporativa. Refere-se à natureza da relação do programador de produção com os objetivos e com o planejamento estratégico da empresa. Alguns programadores descreveram o papel do programador de produção como parte constitutiva da estratégia organizacional. Eles descreveram rotinas de envolvimento direto no planejamento estratégico, como, por exemplo, suas participações nas reuniões de decisão das estratégias corporativas. Nesses casos, são os

programadores os responsáveis pelos indicadores globais da operação. É o grau máximo de envolvimento com a estratégia identificado. Para outro grupo de programadores da produção entrevistados, por outro lado, a estratégia competitiva da organização parece ser algo alheio à sua função. Essa dimensão explicativa nem aparece em seus relatos. Isso porque, para eles, o objetivo do programador seria apenas calcular matematicamente o aproveitamento mais eficiente de recursos e materiais para a demanda estabelecida. Há ainda um terceiro grupo de entrevistados que vê a estratégia apenas como um guia. Os relatos revelam uma percepção de que suas metas e indicadores são definidos por uma instância estratégica da empresa. E isso seria determinante para a sua tomada de decisão. Mas, segundo essa percepção, não seria uma influência mútua, mas, sim, hierárquica, de sentido único. Isto é, para estes entrevistados, a competência está associada a reconhecer cotidianamente as metas estratégicas e decidir em função delas.

\subsection{1.}

\section{Alocação de recursos e materiais}

Ao analisar os dados obtidos nas entrevistas de campo, e considerando as descrições feitas em todos os grupos de entrevistados, chegou-se à primeira categoria descritiva, que foi denominada de "Alocação de recursos e materiais". Se caracteriza por uma concepção que restringe a noção de competência à habilidade requerida para a execução da tarefa essencial da rotina de programação da produção. Isto é, a habilidade necessária para distribuir as quantidades demandadas pelos recursos produtivos disponíveis, e considerando as datas esperadas pela área comercial. Nesses casos, tanto as descrições ostensivas das rotinas quanto os exemplos de práticas 
performativas pareceram não divergir significativamente. Em relação a esse aspecto, foi possível identificar também que os entrevistados desse grupo apresentaram uma tendência a se concentrar na descrição das rotinas individuais, mesmo quando incitados a explorar de maneira mais ampla o papel delas no contexto das rotinas organizacionais e as suas relações de interdependência. Segundo Pentland e Feldman (2005), tomar como referência as rotinas organizacionais, por definição, significa considerar também as relações de dependência, as conexões variadas e as ações de múltiplos participantes. No entanto, as entrevistas dessa categoria descritiva deram pouca ou nenhuma ênfase a esses aspectos amplos e interdependes das rotinas organizacionais. Descrições desse tipo só foram obtidas nas respostas dos entrevistados de outras categorias descritivas. Nesse sentido, pode-se concluir que, por manter sua noção majoritariamente restrita à rotina individual, essa primeira concepção de competência nas rotinas de programação da produção apresenta graus de abrangência e complexidade mais limitados do que as demais.

"Competente é fazer uma programação dentro daquela quantidade que, digamos, a fábrica possa fazer, atender, usando-se dos meios de produção. Eu tenho um estudo da capacidade que existe dentro da fábrica, então eu não vou colocar produção a mais do que aquilo que a fábrica vai conseguir, ou do que aquela máquina vai conseguir fazer para atender... Competente também é (...) cumprir exatamente os prazos e a capacidade que o cliente determinar." (Entrevista 6)

"Planejar corretamente é usar os recursos na sua máxima capacidade. De forma corretamente balanceada, o ganho para a empresa vem maior. [A intenção é que] a gente no final consiga ter produtos mais baratos com uma maior qualidade e com uma maior quantidade também. " (Entrevista 2)

Apesar do enfoque majoritário na rotina individual do programador de produção, a rotina organizacional de programação, mesmo nessa primeira categoria descritiva, é sempre descrita como tendo seu início a partir da demanda, em geral proveniente de um esforço de vendas e previsões. Nesse caso, porém, a dimensão explicativa de conhecimento sistêmico das demais áreas fica restrita ao reconhecimento de uma interface com a área comercial. Essa interface é constituída das atividades de recebimento da demanda a produzir, eventualmente negociação dos números apresentados nela, e, por fim, uma devolução sobre o atendimento a essa demanda colocada pela área comercial. Cabe notar que nessa primeira categoria descritiva foi 
possível identificar que os entrevistados tenderam a atribuir todo tipo de oscilação na demanda não ao mercado, mas sim à qualidade do trabalho da área comercial.

"O comercial normalmente eles fecham contratos com os clientes, tem esse planejamento com os clientes e normalmente eles não enxergam essa parte das capacidades que eu tenho dentro da fábrica. E o que acontece muito é que eles solicitam, tem duas questões, uma questão é que eles não colocam a máxima capacidade, eles não solicitam uma produção que utiliza a máxima capacidade, ou eles fazem um planejamento muito, não é volátil, não é a palavra, é que oscila muito. (...) Toda vez que tem essa oscilação eu tenho que estar fazendo alterações na produção, e sempre que eu faço alterações na produção eu tenho um novo processo, eu tenho um novo treinamento e isso acaba impactando muito na relação de custos porque eu tenho que estar parando a linha para estar fazendo esse tipo de alteração. Então acontece justamente as duas coisas, uma é a questão da oscilação do plano, ele não é linear, e a outra mesmo ele sendo linear ele não utiliza a capacidade inteira da linha." (Entrevista 2)

A partir do recebimento e negociação da demanda, portanto, a rotina organizacional de planejamento e programação da produção é constituída pelas atividades de distribuição dessas demandas pelos recursos produtivos. Essa distribuição é feita por meio de um sequenciamento das operações produtivas em cada recurso ou máquina. Nessa atividade, o programador precisa considerar nos cálculos também o consumo de insumos (materiais). É essa a rotina individual do programador da produção propriamente dita. Em seguida, a rotina culmina no acionamento da atividade produtiva. É quando a produção recebe o programa do que deve ser produzido em cada máquina. Nesse ponto, há uma interface de troca intensa com a área de produção. É esse contexto geral que dá relevância à segunda dimensão explicativa. Segundo os entrevistados, para se programar a produção de maneira competente é preciso entender bem a maneira como se dá o processo de produção. Conhecer quais são as características específicas de seu ambiente produtivo, as restrições existentes e as alternativas disponíveis. Ou seja, na primeira concepção da categoria descritiva, o exercício competente da função de planejamento e programação fica circunscrito à capacidade de construir sequenciamentos para cada máquina que obtenham os melhores resultados segundo os indicadores que mensuram a área de planejamento e programação da produção. Nas entrevistas, tais indicadores apareceram relacionados a volumes e taxas de produção (por exemplo, em unidades por hora), ao percentual de 
pontualidade das entregas, à disponibilidade dos produtos prontos nos estoques para a venda, e à ocupação de máquinas, de forma que se evite ao máximo as ociosidades e as paradas, seja por problemas ou por troca de produtos.

"Fazer o que se espera, o que nos é solicitado, não deixar nenhuma pendencia, errar muito pouco, isso é um programador bom. Aqui é assim, a programação de produção não consiste só em a gente receber uma carteira de demanda, a gente fazer a programação e enviar para as máquinas, a gente acompanha o que eles fazem lá, a gente tem o dever de cercar certas ocorrências que tem lá durante a produção e com antecedência tentar acionar e com habilidade de lidar, de não deixar a desejar.". (Entrevista 3)

"É complicado dar uma definição, mas no cenário em que tu está, [fazer um programação ideal] é conseguir fazer o melhor arranjo possível para atender a demanda lá no final do prazo, sem ter muita perda ou gerar muito custo para a empresa." (Entrevista 20)

Conforme mostra o trabalho seminal de French (1982), programar a produção consiste em buscar a solução para um problema de natureza combinatória explosiva. Em outras palavras, o número de soluções de sequenciamento disponíveis para situações industriais típicas é tão grande que torna impossível, mesmo a computadores de última geração, construir uma solução ótima, isto é, uma solução que verifique todas as alternativas existentes para escolher aquela capaz de oferecer o melhor resultado possível. Estes computadores levariam centenas de milhares de anos para percorrer todas as soluções existentes. Em função disso, os programadores constroem suas soluções com base em métodos de tentativa e erro ancorados na experiência, na intuição e em softwares, que vão desde planilhas até os sistemas de APS (Advanced Planning Systems), que são voltados exclusivamente para apoiar a programação (SAISSE e WILDING, 1997; HILL, COSTA e JARDIM, 1992).

“Acabei tendo que criar uma planilha que me ajudasse a enxergar os números com mais facilidade porque só de olhar ele não me dá os detalhes que eu precisaria, então foi feito uma planilha justamente para me dar esses valores para a gente poder encaixar, e aí depois a gente transformou ela num simulador". (Entrevista 2)

"Programar é fácil. Tu vais sentar aqui, tu já tens as datas de cada setor, tu vais jogar dentro dessa planilha e vai colocar na produção". (Entrevista 18)

Tais planilhas e softwares são alguns exemplos do que a literatura sobre rotinas organizacionais chama de artefatos das rotinas (PARMIGIANI e HOWARDGRENVILLE, 2011; PENTLAND e FELDMAN, 2005). No presente estudo, como 
mostram as citações anteriores, fica evidente o seu papel de instrumento para apoio à tomada de decisão e de "manifestação física" das rotinas (PENTLAND e FELDMAN, 2005). Como já demonstrado, certos aspectos, como o caráter interdependente das rotinas organizacionais de programação da produção, não estiveram muito presentes nas descrições que concebem a competência na programação como sendo a "Alocação de recursos e materiais". No entanto, essas interfaces de relação com outras áreas aparecem de maneira implícita no momento em que os entrevistados se propõem a detalhar o funcionamento de tais artefatos. Assim, as entrevistas corroboraram também a teoria sobre rotinas de duas maneiras. Primeiro, indicando que os artefatos são fontes indicativas sobre os aspectos ostensivos das rotinas (PENTLAND e FELDMAN, 2005). E, em seguida, sinalizando que esses artefatos também melhoram a performance das rotinas (Parmigiani e Howard-Grenville, 2011).

Há aqui, mais uma discussão a ser observada. Ao serem confrontados com uma pergunta direta acerca da concepção de competência, muitos dos programadores entrevistados partiram de um momento inicial de hesitação e, em seguida, buscaram responder com uma lista de conhecimentos, habilidades ou atributos que lhes pareciam universalmente requeridos em função da natureza de seu trabalho. As respostas oscilaram de maneira natural e intuitiva entre as duas visões funcionalistas de competência, tanto a orientadas às pessoas, quanto a orientada ao trabalho (SANDBERG, 2000). No começo das conversas, foi comum ao longo das entrevistas a tentativa de circunscrever as percepções em torno de atributos desejáveis. Segundo Sandberg (2000), estudos com uma abordagem interpretativa da competência concluíram que a maneira como as pessoas efetivamente executam seus trabalhos difere fundamentalmente da maneira como ele é apresentado em manuais, descrições de cargo e treinamentos. Nesta primeira categoria descritiva, ocorreu um exemplo deste aspecto. Invariavelmente os relatos começaram destacando o raciocínio lógico como uma habilidade essencial, que estaria presente numa eventual descrição de cargo. No entanto, ao apresentarem algumas situações extraídas da prática e procurarem justificálas, foram surgindo gradualmente noções mais complexas, particulares e principalmente contextuais da competência. Nesses momentos, o enfoque se voltava às necessidades de operação específicas das suas rotinas organizacionais, muitas vezes se 
distanciando da descrição ostensiva feita anteriormente por eles mesmos. É um ponto que também corroborou de maneira explícita as teorias sobre as diferenças entre os aspectos ostensivo e performativo das rotinas organizacionais (FELDMAN \& ORLIKOWSKI, 2011; PENTLAND e FELDMAN, 2005).

Nesse sentido, ao longo das análises desse trabalho, também foi possível identificar, além da já esperada dissonância entre os aspectos ostensivo e performativo das rotinas (PENTLAND e FELDMAN, 2005; FELDMAN e ORLIKOWSKI, 2011), outro tipo paralelo de dissonância. Uma dissonância que pode ser definida como as dimensões ostensiva e performativa não das rotinas, mas das concepções de competência formuladas pelos programadores. Em outras palavras, a competência evocada pela descrição performativa da rotina muitas vezes não correspondeu às definições ostensivas de competência listadas imediatamente antes. Tais variações nas descrições de competência poderiam ser lidas, portanto, como competências ostensivas e competências performativas.

Para que se possa fazer uma "Alocação de recursos e materiais", isto é, uma alocação que seja considerada competente, é preciso realizar uma função de caráter lógico ou matemático que considera concomitante uma série de variáveis. Além da demanda, proveniente da área comercial, e que é o ponto de partida, o os programadores aos poucos foram indicando que é necessário considerar como dados de entrada dessa conta também outros aspectos, como os roteiros de produção, a disponibilidade real de recursos e materiais de consumo e também os apontamentos do que já foi produzido em cada etapa. Com tais informações eles definem onde, quando e quanto cada etapa de cada produto deverá ser produzida. Para isso, precisam considerar ainda as máquinas alternativas de produção para cada produto, definir os volumes de cada lote e calcular as paradas de troca de produto ou manutenção, apenas para citar os aspectos que apareceram de forma mais recorrente nas entrevistas de campo. Segundo os relatos, a dificuldade se dá porque todas essas variáveis se afetam mutuamente, numa espécie de reação em cadeia. Isso significa que uma decisão de sequenciamento referente a dois produtos específicos em um determinado recurso nunca está restrita a seu âmbito local. Ela sempre irá impactar no sequenciamento de 
todos os outros recursos pelos quais cada um desses produtos passa, e também nos outros produtos que passam por esses mesmos recursos.

"Teria que ter um conhecimento bom do chão de fábrica, ou seja, de como as coisas acontecem no processo, e um bom conhecimento da cadeia de suprimentos, ou seja, os contatos tem que ser muito bom com o pessoal de compras, né?! Os compradores e com o pessoal de produção. Se ele tiver essa rede de contatos muito boa, com certeza ele vai executar o plano dele com eficiência, com rapidez e com uma possibilidade muito grande de não ter que refazê-lo várias vezes". (Entrevista 14)

Além disso, é importante pontuar o caráter dinâmico da função de programação da produção. Há uma máxima entre os programadores que diz que, na verdade, não existe a programação, mas apenas a reprogramação. Está por trás dessa consideração o fato de que toda a programação é sempre refeita, e constantemente. Neste ponto, aparece também a dicotomia entre estabilidade e mudança das rotinas (PENTLAND e FELDMAN, 2005; FELDMAN e ORLIKOWSKI, 2011). As diversas variáveis envolvidas na construção da solução, estão também recorrentemente sujeitas a imprevistos e mudanças. Alguns exemplos citados pelos programadores são: quebras de máquina, absenteísmo, falta de materiais e solicitações de apressamento por parte de clientes importantes. Tais ocorrências fazem com que todo o trabalho precise ser refeito rotineiramente. Nesse sentido, foi possível perceber que os programas liberados para acionar a produção costumam perder a validade frequentemente. Em situações assim, a produção passa a pressionar a programação para a liberação dos novos programas o mais cedo possível, o que faz com que os programadores estejam sempre trabalhando com prazos curtos e sendo pressionados pela rapidez na execução de suas tarefas. Assim, a rotina geral é sempre a mesma, mas essas oscilações de contexto fazem com que as etapas percorridas para realização de toda a rotina sejam sempre renovadas à casa execução.

"Nós temos vários níveis da organização, até dentro do PCP. Então, nós trabalhamos com gerência, coordenação, engenheiros, supervisores. É o seguinte, se um nível não consegue resolver, ele passa para o outro. Se o outro nível não conseguir resolver, passa para outro. Tem duas horas esse não atendimento, ele tem que estar já para a gerência, a gerência tem que chegar numa decisão. (...) Quando eu faço um plano (...) eu consigo ter uma análise rápida de qualquer lugar que eu esteja, para qual cliente posterior ela pode servir. (...) Se eu não consigo resolver, vai para uma gerência (...) são decisões rápidas que tem que ser tomadas, porque nossas linhas hoje são gargalhos não em função de demanda.” (Entrevista 10) 
Dentro deste contexto de velocidade e mudança constante, portanto, a competência do programador, segundo a concepção da primeira categoria descritiva, fica sujeita a essa habilidade essencial que os programadores chamaram a de raciocínio lógico. É a habilidade atribuída à capacidade de considerar todas as variáveis relevantes e calcular rapidamente soluções alternativas para a Alocação da demanda nos recursos produtivos, de acordo com cada cenário vigente. Nessa concepção, ainda que os programadores conheçam essas variáveis e tenham noção de que elas provêm de outras áreas, ele as tratam meramente como dados de entrada do problema a resolver. Ou seja, nessa primeira concepção de competência não costuma estar em jogo administrar, controlar, mediar ou negociar com essas variáveis, como ocorre com a segunda categoria descritiva. Além disso, os relatos agrupados na concepção de competência se concentraram na rotina individual e na interface com a área de produção. As demais áreas, quando muito, foram lembradas como pano de fundo. Para um segundo grupo de relatos, no entanto, a competência vai aparecer essencialmente atrelada à relação com as demais áreas, conforme se verá a seguir.

\subsection{2. Mediação entre diferentes áreas}

A segunda categoria descritiva, apresenta uma concepção que pode ser compreendida como mais ampla e mais complexa do que a primeira. O foco deixa de ser apenas o resultado da conta de alocação, e passa a considerar diretamente também a administração da relação com outras as áreas da empresa. É o que está sendo denominado de "Mediação entre diferentes áreas". Nessa concepção, as rotinas organizacionais de planejamento e programação e produção foram definidas pelos entrevistados a partir de uma dinâmica de intermediação de interesses entre diferentes áreas envolvidas na operação. É uma visão de competência essencialmente relacionada à dimensão explicativa de conhecimento sistêmico. Isso porque, segundo as entrevistas agrupadas nessa categoria descritiva, o exercício competente da programação da produção passa principalmente por se ter um conhecimento geral sobre os aspectos críticos das demais áreas. Tais aspectos envolvem as atividades, as metas, as ferramentas disponíveis e as restrições que são impostas a cada área. 
"O programador tem que ter esse conhecimento geral. É uma pessoa que faça a interligação entre todas as áreas envolvidas e que consiga enxergar todas as necessidades. É claro que ela não tem o conhecimento técnico das outras áreas, mas essa pessoa precisa ter um conhecimento de como funcionam todas as áreas. Alguns setores vão ter mais dificuldades do que outros, uns vão ser mais habilidosos para resolver problemas, então o programador tem que ter esse conhecimento geral para conseguir entender tudo e enxergar onde possa ter uma falha, onde a pessoa não está fazendo o que deveria estar fazendo, saber por que aquilo está acontecendo, por que não foi resolvido e quando vai ser resolvido. Para mim, a pessoa tem que ter a habilidade de conhecer o todo da fábrica, não no detalhe, mas ter noção de como funciona todo o processo." (Entrevista 16)

"Nós temos uma visão muito boa, um pouco até mais ampla do que por exemplo, um coordenador de produção, que cuida só de uma área, de uma célula. Já teve casos de ter uma sequência de um produto e um material num volume alto em que já eram definidas rotas e todo planejado, cargas montadas das máquinas. A gente tinha que verificar se a gente poderia utilizar com esse volume, com esse material que estava planejado. Puxar o material, por exemplo, de uma outra semana, de uma outra quinzena e nesse caso garantir setup. O que ocorreu nessa situação? A gente avaliou, a gente viu que conseguiria atender a matéria-prima para essa segunda carga, por exemplo. E posso dizer, assim, sobre a produção e maximizar a utilização da máquina. Você pode ganhar, por exemplo, um dia de setup. E isso é um caso que até ocorre normalmente, isso é algo bem-sucedido, que eu vejo na visão de programação, é você ter essa visão um pouco além. " (Entrevista 17)

Nas descrições das entrevistas, foi possível identificar que existe uma série de variáveis que interferem diretamente nas possibilidades e alternativas de programação. Tais variáveis são ações e pacotes de informação cuja origem está em outras áreas da empresa. Nesse sentido, a dimensão explicativa de raciocínio lógico é entendida como sendo a habilidade para analisar alternativas de cálculo, com foco na apuração, análise e interpretação das variáveis provenientes dessas demais aéreas.

"Se eu acabo sobrecarregando o setor, e aí o setor não consegue dar conta de entregar o lote no tempo médio que a gente calculou. (...) É aí que entra a relação do programador com a fábrica. Então o que a gente tenta é a cada lote fazer uma configuração de fábrica diferente para atender aquele lote. (...) Para poder aumentar a capacidade produtiva daquele setor. (...) Mas para isso a gente tem que ter a real noção de tempo de cada setor, para que seja realmente possível esse remanejamento de pessoas. Ou é pessoas, ou é realmente trabalhar com o prazo de entrega. E aí a gente meio que mescla o prazo, em vez de entregar em um lote, entregar em dois, e negocia com o comercial." (Entrevista 8)

"Como nós não temos um sistema próprio, não temos um sistema de gestão integrada, para mim a maior dificuldade ainda é na questão das capacidades, das inserções manuais, de dependermos do cálculo da engenharia, onde nós não temos registro em sistema de cronoanálise. (...) Então nós ficamos dependentes da engenharia, ficamos dependentes de materiais para nos enviar planilhas em excel, o que não é tão confiável com esses dados. (...) Então, dessa produção passada, nós simulamos um 
futuro de acordo com aquela capacidade que aquela linha conseguiu atingir. Um exemplo esse mês que foi até interessante, nós do PCP, programadores, fizemos uma sugestão para vendas sobre uma capacidade produtiva que a engenharia nem tinha visão. Nós fizemos o levantamento por entrevista do supervisor de produção e da engenharia, no que disseram que o plano de produção seria capaz, era viável de ser atingido". (Entrevista 4)

Cabe observar aqui que em alguns casos foi possível identificar uma divergência entre as concepções do programador e a de sua respectiva empresa acerca do que constitui a competência nas rotinas de programação. É como se a visão da empresa pudesse ser enquadrada em uma categoria descritiva e a percepção de seu programador da produção em outra. Algumas entrevistas sugerem, por exemplo, que programadores de produção que concebem a competência das rotinas organizacionais na segunda categoria descritiva podem estar inseridos em culturas organizacionais alinhadas com a primeira e mais restrita categoria descritiva. Ou seja, foi possível identificar em alguns casos dissonâncias entre a concepção de competência dos entrevistados e a que eles próprios relataram ser as de suas respectivas empresas. Nesses casos, se mostrou confirmada a teoria de que a cultura organizacional se impõe às rotinas (BERTELS, HOWARD-GRENVILLE e PEK, 2016). Na prática, essa imposição pode ser especialmente notada pelo poder que os artefatos demonstraram para delimitar as rotinas organizacionais e normatizar as suas práticas (FELDMAN e ORLIKOWSKI, 2011; PARMIGIANI e HOWARD-GRENVILLE, 2011).

Além das relações mais evidentes com os setores comercial e produtivo, a área de planejamento e programação da produção lida recorrentemente com diversas outras áreas. A validação da disponibilidade de matéria-prima resulta de uma relação com o setor de compras, por exemplo. Há outros exemplos que puderam ser encontrados. As datas de consumo dos insumos e da finalização dos produtos interferem diretamente no setor de almoxarifado. Já as datas de entrega precisam naturalmente considerar a área de logística. A disponibilidade das máquinas está sempre sujeita a área de manutenção. Os roteiros de produção de cada produto demandado são resultado do trabalho da área de engenharia. E assim sucessivamente.

Nesse sentido, a concepção da segunda categoria descritiva define a competência da programação de produção como sendo a habilidade de mediar tanto os objetivos quanto as restrições de diferentes áreas da empresa. Os relatos das entrevistas mostram 
ainda que as soluções encontradas nem sempre serão percebidas como positivas por todas essas áreas afetadas. Tome-se como exemplo o caso de uma solução de programação em que se atendeu a uma necessidade comercial de produzir uma ampla variedade de produtos em pequenos lotes. Esse arranjo foi prejudicial para os indicadores que medem a área produtiva. Fabricar muitos lotes pequenos e de produtos diferentes obriga a produção a fazer um maior número de paradas para a troca. Com isso, a sua taxa de ocupação de máquinas será menor, assim como o volume total de produtos feitos no mesmo período. Em algumas entrevistas esse tipo de situação é apontado como uma recorrente causa de conflito na empresa. Segundo a concepção da segunda categoria descritiva, portanto, cabe o programador fazer a mediação de situações conflituosas, negociando interesses e liderando a tomada a decisão.

“Então, às vezes precisa um pouco de um feeling mais político pra conseguir fazer isso [mudanças na programação] sem tanto desgaste, muitas pessoas são reativas à esse tipo de alteração.” (Entrevista 7)

"Pra nós, sabe, o planejador tinha que estar lá no chão de fábrica, toda hora, vendo o que é que eles estavam fazendo. O chefe anotava muita coisa, e o chefe às vezes enganava. Dizia que estava pronto pra ganhar uma meta e não estava. Então, diante disso, de necessitar preparar o material pra facilitar a vida da seção e o controle, a gente uniu a ideia e disse: "então vamos trazer para o PCP e vamos liberar". Até porque liberar a produção, vamos dizer, é [tarefa] do PCP. (...) Então, nesse quadro a gente tem toda a programação. Vamos supor que quando a gente está programando para montar qualquer sistema, estão lá: o tempo da obra, a programação da montagem e todos os subcomponentes ao lado. Daí, tem as datas do fornecedor e os prazos. Como compras também está nessa reunião, muitas vezes a gente pega o atraso da produção nela. (...) Com a participação de todos, cada um dá a data que atende, a gente discute assim. (...) A tomada de decisão é feita por nós. É melhor no nosso quadro". (Entrevista 5)

Como mostram os relatos, o programador precisa negociar e comunicar bem o resultado final de suas programações. Cabe a ele manejar de forma competente a relação entre as diferentes áreas no sentido de construir um engajamento global dos diferentes setores em prol da execução dos programas que ele define. As entrevistas sugerem que, segundo essa concepção, as estratégias utilizadas em tais processos de negociação constituem uma dimensão essencial da competência nas rotinas organizacionais de planejamento e programação da produção. Na prática, os relatos sugerem que uma boa programação é sempre uma solução que foi negociada em reuniões com as demais áreas. Nesses casos, a estratégia de negociação utilizada por 
eles pode ser entendida como sendo a chamada negociação integrativa (integrative negotiation). Para Thompson, Wang e Gunia (2010), as negociações integrativas ocorrem quando o resultado negociado satisfaz os interesses de ambas as partes, o que significa que o resultado final não pode ser melhorado sem prejudicar uma ou mais das partes envolvidas. No caso específico de programação da produção, o que é entendido como sendo estas partes envolvidas no processo de negociação são justamente as áreas da empresa. Em outras palavras, os "interesses" das partes são representados pelos indicadores que avaliam o desempenho de cada uma das áreas envolvidos no processo de negociação do programa de produção que vai reger as decisões operacionais.

"Como nós temos os registros das posições por dias, nós fazemos relatórios diários e mostramos (...). Por exemplo, o que a engenharia disse que era capaz? 100, mas o PCP foi e programou 120. E a produção atingiu os 120. PCP manteve constante esses 120 na programação e a produção conseguiu atingir, sem ter esforço, sem comprometer (...), sem ter muita fadiga. Ou seja, está dentro da legislação e normas, com esse registro diário, com esses dados, como a gente contém dados em mãos, ninguém contesta. Como nós temos dados em mãos e é sistema, dá para gerar relatório. Nós conseguimos levar à mesa da gerência e conseguimos convencer que nós temos mais capacidade, a partir daí nós temos duas decisões: ou reduzimos a capacidade para melhorar a efetividade da mão de obra, dando férias, ou nós convencemos suprimento e vendas, se houver interesse em aumentar a demanda". (Entrevista 4)

"Eu acho que isso é um dom menos técnico e mais um lado de comunicação mesmo, assim, a pessoa ser mais comunicativa, negociador, porque tem que ter um jogo de cintura, como se fosse o outro lado do comercial. Até porque você está lidando com pessoas que têm uma boa capacidade de negociação (...) Se ele [o programador] não souber ter um jogo de cintura, uma boa comunicação oral, sair um pouco da mesa e ir lá no setor comercial, fazer reuniões, ele não consegue, vai ser enganado (...) Às vezes o cliente pediu para a data, mas se o PCP, junto com o representante, que é a pessoa ali, o gerente de vendas que está em contato com o cliente direto, não tiver o entendimento e a conversa de se descobrir se realmente aquele pedido vai ter condições de carregar, ser recebido ou não, a gente vai ser resolvido na briga.(...) Então a gente [programação] tenta equilibrar isso.” (Entrevista 8)

Em suma, nas entrevistas da segunda categoria descritiva, a competência em planejamento e programação da produção aparece recorrentemente associada à condução do relacionamento com todas as demais as áreas afetadas pela programação. O papel desse relacionamento é criar um senso de construção conjunta das soluções que garanta um engajamento global de todo o sistema. Desde as partes envolvidas na rotina de planejamento e programação da produção em si, até as rotinas seguintes, que são consequência das decisões finais da programação. 
Nesse sentido, pode-se afirmar que a segunda categoria descritiva trouxe o achado mais inesperado do ponto de vista das expectativas originais de pesquisa. Em relação à primeira categoria descritiva, circunscrita à rotina individual e à tarefa básica de programação, pode-se dizer que já era esperada. Isso porque tal concepção está alinhada com a abordagem funcionalista que tradicionalmente é feita em relação à área de planejamento e programação da produção. Na outra extremidade do espaço de resultados, conforme se verá a seguir, o entendimento da programação da produção como um agente não só de execução tática, mas também de formulação estratégica era justamente um dos principais aspectos que se queria verificar com o estudo. Mas foi a segunda categoria descritiva, ao identificar a competência nas rotinas de planejamento e programação da produção como sendo o cumprimento de um papel de mediação entre as diferentes áreas envolvidas na operação produtiva - que se encontrou uma concepção particularmente nova e que não havia sido antevista preliminarmente. Até se pode argumentar que a mediação entre as áreas comercial e produtiva é uma função esperada para a programação. No entanto, a concepção que emergiu dos relatos foi além disso. Ela coloca a área de planejamento e programação da produção como um mediador de toda a função operativa da indústria. Os programadores veem a competência associada principalmente a habilidade de mediar, de se relacionar, de negociar. O conhecimento das demais áreas se torna mais relevante do que o conhecimento específico do processo produtivo - que é o objeto direto do trabalho de programação. Os indicadores locais, que são de responsabilidade do planejamento, passam a ter o mesmo peso de outros indicadores cuja responsabilidade provém das demais áreas. O programador é uma espécie de juiz que media a tomada de decisão coletiva. A partir dessa concepção, portanto, ganhou relevância o papel dos tipos de estratégias de negociação utilizados no exercício das rotinas de programação da produção. Segundo essa percepção, a competência para mediar é mais importante do que a competência para programar. Conforme já visto, os relatos mostram que a competência em frequente medida estava associada mais especificamente à capacidade de utilizar a estratégia de negociação integrativa (BRETT e THOMPSON, 2016; THOMPSON, WANG e GUNIA, 2010). O uso da estratégia integrativa de negociação mostra que o objetivo é construir nos programas de produção soluções que tenham 
origem na mediação e que sejam capazes de equilibrar ou nivelar os indicadores locais de cada uma das áreas envolvidas na operação. O programador alinhado com essa concepção não está preocupado apenas em gerir bem as suas restrições, extraindo o melhor resultado segundo os indicadores que medem o seu próprio desempenho. Nessa concepção, ele vislumbra com clareza a relação de interpendência, própria às rotinas organizacionais (PARMIGIANI e HOWARD-GRENVILLE, 2011; PENTLAND e FELDMAN, 2005) e deve ser capaz de priorizá-las. Nesse sentido, ele é um gestor da rotina organizacional como um todo, se torna o responsável por seu desempenho.

Assim, a concepção do programador da produção como um mediador das diferentes áreas operativas da empresa também já começa a defini-lo como idealmente dotado de uma preocupação e de uma visão globais. É a dimensão explicativa referente ao "envolvimento com a estratégia corporativa". Em relação a esse envolvimento estratégico, é possível notar pelos relatos apresentados que há outro entendimento comum sobre o que é o exercício competente das rotinas organizacionais de planejamento e programação da produção. Os programadores sinalizaram para a importância de se desenvolver uma capacidade de liderança para a tomada de decisão

na operação. Note-se, no entanto, que nesse caso não é uma liderança hierárquica. É apenas o reconhecimento da centralidade na mediação das relações entre as outras áreas operativas. Ou seja, ainda que precise ver e mediar o todo, essa concepção não situa a programação de produção dentro do âmbito das estratégias da empresa. A competência aqui, mesmo sendo vista de forma mais ampla e complexa, ainda é majoritariamente atrelada à execução das estratégias, nunca à sua formulação. Em contrapartida, há um terceiro grupo de entrevistados que vê nas rotinas organizacionais de planejamento e programação da produção um papel central na gestão estratégica das empresas. Tal percepção é apresentada e discutida na categoria descritiva a seguir.

\subsection{3.}

Gestão tático-estratégica da operação

A concepção que configura a terceira categoria descritiva é a que foi considerada como a mais ampla e também a mais complexa. Segundo essa percepção, tanto calcular rapidamente boas alocações de demanda, quanto mediar a relação entre as diferentes 
áreas que se relacionam com a produção, são habilidades necessárias e importantes, mas não são as principais. Segundo os entrevistados que compõem esse grupo, o que define competência na programação de produção é fazer o que se está denominado aqui de gestão tático-estratégica da operação. E o que caracteriza essa gestão táticoestratégica da operação é o cumprimento de um papel central não só na operacionalização, mas também na elaboração das estratégias corporativas. Envolve agora uma liderança hierárquica das atividades de programação, sempre no sentido de organizar a operação para os objetivos estratégicos da empresa. Ou seja, há uma dimensão tática, caracterizada pela execução operacional das metas corporativas. Mas há também uma dimensão estratégica, que se caracteriza pela participação efetiva na formulação do planejamento estratégico da empresa. Por essa razão, é uma concepção que parece ser mais frequente em empresas que posicionam a programação da produção em degraus hierárquicos mais elevados dentro da organização.

“É importante que esse programador, esse planejador, seja bom negociador. E ele tem que ter empatia com as demais áreas. Se possível, estar aberto a conhecer essas áreas, conhecer as necessidades do Comercial, conhecer as necessidades da Produção, sem estar julgando previamente, dizendo 'Não, esses caras estão malucos, o que eles querem não funciona'. Então, acho que essas são as principais competências do programador. Essa abertura de se colocar no lugar do outro na cadeia de produção e na cadeia [produtiva] da empresa." (Entrevista 12)

"Esta é uma premissa dentro da empresa que a gente trabalha hoje, as estratégias são originárias da logística [planejamento da produção e distribuição].” (Entrevista 9)

Na prática, conceber as rotinas de planejamento e programação da produção como responsáveis pela "gestão tático-estratégica da operação" significa conceber a competência do programador pela sua capacidade de atuar diretamente nas decisões estratégicas. Os relatos indicaram que o programador precisa ter uma visão do todo e estar alinhado com os objetivos corporativos. Segundo alguns deles, cabe à programação de produção atuar desde as previsões de cenários futuros e análises de investimento, até liderar as tomadas de decisões táticas de curto e médio prazo. É preciso ainda considerar os objetivos globais e os resultados financeiros decorrentes de cada escolha de sequenciamento da produção.

“A competição é cada vez mais acirrada, então o planejamento ele não pode se eximir do papel estratégico que ele tem dentro do resultado da empresa, ele tem que estar sempre à frente e sempre buscando coisas, soluções novas. (...) O planejamento é o 
meio para transformar a necessidade do comercial e a visão dos acionistas, do que tem que ser entregue para o mercado. E olhando o que se tem como recurso produtivo. Como é que se consegue transformar esse desejo do acionista em produto e em entrega? Então, esse papel estratégico quer dizer que (...) o planejamento vai achar uma solução, nem que a solução seja comprar novos equipamentos ou abrir uma nova planta ou fechar uma planta que não é mais adequada para os novos tempos. Então eu acho que o planejamento tem que assumir esse papel, cada vez mais tirar isso da cabeça do dono [da empresa]. " (Entrevista 12)

"A gente atua mais nas decisões, pelo menos na área de planejamento, depois tem o controle da produção, claro, que eu acho também muito importante, mas a área de planejamento é o antes. Você tem que prever o que vai acontecer, você tem que ter dados suficientes para você agrupar e fazer com que o planejamento estratégico que foi proposto na área da empresa aconteça. Então eu acho que tem que pensar muito, você tem que sempre estar considerando todos os pontos da empresa. Você tem que ter uma visão global.” (Entrevista 19)

De acordo com as entrevistas, os programadores de produção que foram agrupados nessa concepção não veem a dimensão explicativa do raciocínio lógico como necessária ao exercício competente das rotinas de planejamento e programação da produção. Para eles, as rotinas de dados e cálculos distributivos devem idealmente ser apoiadas por software, mesmo que sejam planilhas automatizadas. Nas entrevistas, os programadores demonstraram considerar que o investimento em soluções tecnológicas para o desempenho da programação é estratégico. Para eles, investir em tecnologias computacionais de apoio à programação reflete diretamente no desempenho dos indicadores globais da empresa. A segunda dimensão explicativa, referente ao conhecimento técnico, também aparece associada à utilização de sistemas computacionais para lidar com uma gama de dados ampla e composta de distintas variáveis. Ou seja, para eles, não basta ter o conhecimento técnico, mas sim dominar os mecanismos que o permitam lidar com o volume das informações e sua dinâmica de mudança constante.

"Tem que ser alguém que realmente não tenha medo nenhum do computador, que veja o computador como uma ferramenta de apoio e saiba explorar. (...) Eu vejo muitos profissionais na área de planejamento que conhecem Excel, tem Excel avançado, mas não se vê a pessoa usando o Excel como uma ferramenta solucionadora de problemas. E ele consegue no máximo automatizar uma rotina, mas ele não consegue usar a planilha para gerar novas informações, gerar possibilidades diferentes. São poucos os planejadores que eu cruzei na minha carreira que, se você dá o problema para ela, ela usa a tecnologia para resolver o problema." (Entrevista 12) 
"E, claro, buscando ter conhecimento nas ferramentas. Principalmente hoje, para trabalhar com sequenciamento, trabalhar com programação, tem a ferramenta Excel, que é extremamente auxiliativa (sic). Então, análise e busca de dados é através do Excel. Então, conhecimento avançado do Excel é essencial. E tem também as ferramentas que a empresa utiliza, principalmente o MRP e o APS, tem que ter um conhecimento extremamente avançado dessas ferramentas." (Entrevista 9)

"Quanto mais variável é a demanda, maior é a dificuldade de tu programar. Se tu tem um ERP bem completo, se tu tem um simulador tipo um APS, a tua vida fica um pouco mais fácil. A gente vai mudando as regras, vai reconfigurando ele e ele vai te dando sugestões. Quando tu tem um ERP mais fraco, digamos assim, que depende muito das pessoas, a primeira dificuldade é mudar a forma do planejador pensar. (...) A principal questão na programação é que cada vez mais a gente necessita de recursos tecnológicos, pra conseguir fazer, pra acompanhar essas mudanças tão rápidas." (Entrevista 12)

A dimensão explicativa referente ao conhecimento das demais áreas da empresa é naturalmente essencial para a concepção dessa terceira categoria descritiva. A partir das entrevistas, encontra-se uma definição de competência no planejamento e programação da produção que está relacionada a um alinhamento com a competividade da empresa. As entrevistas relatam a necessidade de se conhecer as metas e restrições dos demais setores da operação. Nesse caso, não apenas para mediar, mas também para avaliar e projetar cenários futuros, estudando alternativas de curto, médio e longo para, por fim, decidir estrategicamente. Espera-se do responsável pelo planejamento e programação da produção um conhecer sobre a natureza da função das demais áreas e seus respectivos papéis no desempenho geral da operação.

Às vezes ele tem que deixar de ser um pouco analítico e ser executor rápido. Extremamente comunicativo, é uma área que lida com públicos extremamente diferentes, ele lida com público comercial, públicos técnicos e direto com o operacional, então é uma pessoa que precisa saber se comunicar com diferentes níveis. Também o programador precisa conversar com gerências, seja alta gestão ao nível mais baixo, digamos assim, que é o operacional dentro da empresa. (...) Talvez não seja o mais importante uma formação de engenharia, são mais importantes as característica pessoal, mesmo, de comportamento, porque é uma área extremamente estressante, (...) os problemas que a empresa tem passam na logística para tomar uma solução ou achar uma alternativa. (Entrevista 9)

"Um bom planejador consegue comunicar o que a empresa precisa para ser mais rentável, consegue administrar isso com o cliente e consegue ter uma visão técnica apurada.[...] Toda mudança [relativa à desligar ou transferir pessoas], a gente envolve a diretoria, com essa informação a produção e o PCP voltam ao Departamento de Recursos Humanos para fazer os acordoa com o sindicato..” (Entrevista 11) 
Nesse sentido, a área de planejamento e programação da produção, segundo essa concepção, também tem um papel importante na mediação entre as áreas. Porém, ao contrário da segunda categoria descritiva - em que as negociações entre áreas são pautadas pelo equilíbrio dos resultados locais de cada área - na gestão tático-estratégica da operação as estratégias de negociação utilizadas estão reguladas pelos indicadores estratégicos globais, independente das posições locais. Conforme mostram os relatos apresentados, a relação entre as áreas é lida como uma relação recíproca de parceria em que a meta é obter os melhores ganhos para o sistema, mesmo que isso se dê em função do prejuízo de indicadores locais. A competência, portanto, está definida também pela utilização de estratégias de negociação do tipo "parceria ou reciprocidade" (BRETT e THOMPSON, 2016). Cabe às rotinas de programação, segundo essa concepção de competência, ter a capacidade de garantir essa relação recíproca de parceria em prol de objetivos comuns. Objetivos esses que são os resultados estratégicos da operação, avaliados por indicadores globais.

Nesse ponto, é pertinente retomar também a discussão sobre a centralidade da área de planejamento e programação da produção na motivação do presente estudo. A literatura prévia relacionada a operações e à indústria já sugeria que, em um contexto de globalização acelerada pelas mais recentes tecnologias de informação e comunicação, as engenharias de produto e de processo de empresas concorrentes passaram a se assemelhar de maneira visível (HILL e HILL, 2009; COSTA e JARDIM, 2015). Dentre os inúmeros esforços por inovação, aqueles bem-sucedidos tendem a ser rapidamente incorporados por concorrentes. Nesse cenário, a literatura (COSTA e JARDIM, 2015; CARVALHO, 2005, SAISSE e WILDING, 1997) prega que as empresas vão se diferenciar por sua capacidade de entregar seus produtos cumprindo requisitos rapidez, prazo, qualidade, variedade e flexibilidade. Por isso, a gestão de operações, em âmbito geral, e a função de planejamento e programação da produção em particular, vem ganhando um inédito papel decisivo na competividade (COSTA e JARDIM, 2015; CORREA, PAIVA e PRIMO, 2010). Caberia a elas reger as decisões operacionais capazes de atender a esses objetivos. Restava saber, portanto, se essa mudança em curso já estava incorporada à cultura das empresas indústrias. E, mais especificamente, se os programadores de produção, ao pensar o exercício competente 
de sua função, consideravam o seu papel na estratégia corporativa. Sobre essas questões, foi interessante notar, portanto, que o papel estratégico da programação já está claro e foi descrito de maneira explícita quando os entrevistados ponderam sobre o que é uma programação da produção competente. E em uma proporção que ficou acima expectativas iniciais do estudo. 


\section{2}

\section{O Espaço de Resultados}

\author{
Categorias de Descrição \\ (Concepcões)

1. Alocação de recursos e
materiais

\section{Mediação entre diferentes áreas}

\section{Gestão tático- estratégica da operação}

$$
\begin{aligned}
& \text { Intermediar as práticas e } \\
& \text { os objetivos das } \\
& \text { diferentes áreas } \\
& \text { envolvidas na operação }
\end{aligned}
$$

\section{Dimensões Explicativas (Atributos da competência)} parte 1 de 2

$\begin{array}{ccc}\text { Raciocínio lógico } & \begin{array}{c}\text { Conhecimento técnico (do } \\ \text { processo produtivo) }\end{array} & \begin{array}{c}\text { Conhecimento sistémico } \\ \text { (de outras áreas) }\end{array}\end{array}$

Conhecimento da área comercial e de suas margens de negociação para cumprimento da demanda.

Habilidade para analisar alternativas de cálculo com foco na apuração, análise e interpretação das variáveis.
Conhecer a dinâmica da produção para para negociar os programas, as restrições e objetivos compartilhados

\section{Capacidade de usar} sistemas informatizados para resolver a dimensão matemática da programação.
Conhecer a realidade da fábrica para avaliar cenários e tomar decisões considerando médio e longo prazo

\section{Conhecimento geral sobre as metas e restrições das demais áreas que afetam e são afetadas pela programação.

Conhecer a natureza da função das demais áreas e seu papel no desempenho global da operação.

Quadro 2 - Espaço de resultados (outcome space) das concepções de competência nas rotinas organizacionais de programação da produção (1/2). Elaborado pelo autor. 
Dimensões Explicativas (Atributos da competência) parte 2 de 2

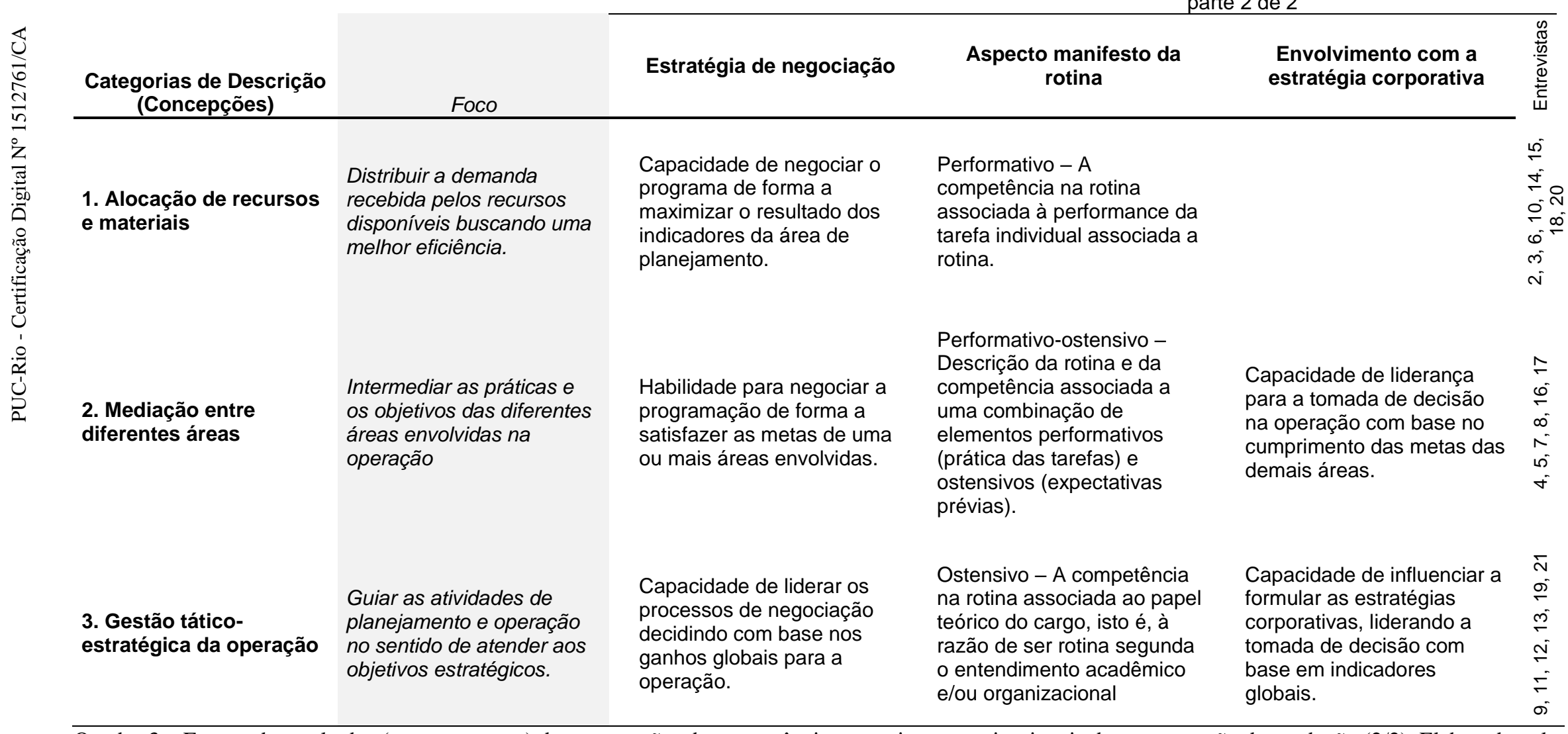

Quadro 3 - Espaço de resultados (outcome space) das concepções de competência nas rotinas organizacionais de programação da produção (2/2). Elaborado pelo autor. 


\section{5 Considerações finais}

Neste capítulo serão apresentadas as principais contribuições do estudo e abordados possíveis desdobramentos futuros. Para isso, começaremos com uma retomada do objetivo de pesquisa, comentando a motivação e os principais conceitos que o fundamentam. Em seguida, será indicado brevemente o percurso metodológico trilhado pelo estudo. Por fim, ao longo de todo o capítulo, serão pontuadas as contribuições da pesquisa propriamente ditas.

O presente estudo buscou compreender a constituição da competência nas rotinas de planejamento e programação da produção. Esse objetivo, portanto, foi organizado a partir de três conceitos estruturais: planejamento e programação da produção, rotinas organizacionais e competência. Cada um desses conceitos pode guardar significados múltiplos e ser abordado de maneiras distintas. Nesse sentido, a primeira tarefa, antes de ir a campo, foi circunscrever as bases desses conceitos principais para, em seguida, postular como a pesquisa se posicionou frente a cada um deles.

O primeiro dos conceitos, e que constituiu a motivação e o objeto de análise, é a área de planejamento e programação da produção. Mais do que delimitar o que é a referida área, qual é o seu papel e quais são as atividades que constituem suas rotinas - aspectos esses que o próprio método fenomenográfico sugere devem emergir das entrevistas de campo - cabe estabelecer inicialmente os motivos pelos quais o planejamento e programação da produção foram escolhidos como objeto de estudo, dimensionando sua relevância dentro do contexto organizacional contemporâneo. Sobre esse aspecto, é importante ressaltar que as mudanças pelas quais passam as organizações nos últimos anos. Particularmente, em decorrência principalmente do fenômeno da globalização somado aos avanços nas tecnologias de comunicação, a gestão de operações no chão-de-fábrica e, mais especificamente, a atividade de programação da produção, ganharam papel estratégico para as empresas industriais dentro de seus mercados (HILL e HILL, 2009). É uma mudança de paradigma. O presente estudo pôde destrinchar a maneira pela qual esses aspectos se verificam nas rotinas organizacionais de planejamento e programação da produção e no modo como os programadores concebem a competência no exercício de suas funções dentro desse 
contexto atual. O papel estratégico da área de planejamento e programação da produção se verificou efetivamente presente em algumas empresas, conforme os relatos pertencentes à terceira categoria descritiva puderam evidenciar.

Para atingir o objetivo central do estudo, também foi preciso estabelecer o que são as rotinas em si, e porque elas constituem uma unidade análise pertinente e útil à proposta de trabalho. A definição de rotinas organizacionais feita pelo presente estudo se inscreve, portanto, em uma discussão que possui sólidas raízes conceituais (MARCH e SIMON, 1958; WINTER e NELSON, 1982) e que vem ganhando aprofundamento e maior destaque nos últimos anos (PENTLAND e FELDMAN; 2005; PARMIGIANI e HOWARD-GRENVILLE, 2011, FELDMAN e ORLIKOWSKI, 2011). Pentland e Hærem (2015), por exemplo, definem as rotinas como sendo conjuntos de práticas, ou padrões de ações individuais e coletivas, que são circunscritas por algum contexto material ou social. O posicionamento do presente estudo, se inscreve na linha de pensamento que entende que esses padrões de ação explicam mais sobre o comportamento organizacional do que as abordagens centradas em pessoas ou decisões (PENTLAND e FELDMAN, 2005; PARMIGIANI e HOWARD-GRENVILLE, 2011; PENTLAND e HÆREM, 2015). Outro aspecto marcante em relação às rotinas organizacionais e que permeou às discussões dos achados diz respeito ao papel da cultura organizacional como origem desse repertório de estratégias de ação (BERTELS, HOWARD-GRENVILLE e PEK, 2016). Sobre essas discussão, foi possível identificar na análise das entrevistas uma recorrente menção ao uso de softwares de apoio a programação da produção. Nesse processo, a análise dos relatos demonstrou também que independente dos graus variados importância atribuídos aos softwares de programação, tantos pelos programadores quanto pelo que descreveram ser o de suas empresas, eles estão sempre presentes nos relatos. Nesse sentido, pode-se dizer também que esta frequente menção à importância desses sistemas computacionais revela, às vezes de maneira direta e noutras indiretamente, como a cultura organizacional efetivamente molda os artefatos das rotinas de programação de produção e, com isso, determina os resultados esperados delas.

Outro aspecto significativo da teoria sobre rotinas organizacionais, diz respeito à variação entre as dimensões ostensiva e performativa das rotinas (PENTLAND e 
FELDMAN, 2005; FELDMAN e ORLIKOWSKI, 2011, TURNER e FERN, 2012). Significa que as maneiras como as pessoas executam as suas rotinas na prática costumam ser diferentes da maneira como essa mesma rotina é descrita formalmente. Nesse estudo, identificamos que não só as etapas e características das rotinas podem variar dentro de seus âmbitos ostensivo e performativo. Variam também as percepções que um mesmo praticante da rotina tem acerca de alguns conceitos presentes no cotidiano de suas rotinas. Particularmente, no caso do presente estudo, o conceito de competência. Em um momento inicial das entrevistas, os programadores tenderam a descrever a competência a partir de uma lista de habilidades essenciais ou universais. Nesses momentos, o discurso se assemelhava a uma descrição de cargo, caracterizando o que propomos interpretar como uma espécie de lista de "competências ostensivas". Em segundo momento, conforme as descrições de práticas das rotinas foram se desdobrando, se mostrou recorrente o surgimento de mudanças nas conceituações individuais de competência. $\mathrm{O}$ entendimento do fenômeno ganhou complexidade e competência. E terminou por ser descrito de forma renovada a partir outras capacidades desejáveis. Estas novas concepções de competência que emergiram, portanto, eram mais contextuais, especificas e derivadas das práticas, o que nos permite a classificálas como "competências performativas".

Ainda em relação ao conceito de competência - particularmente no contexto das rotinas organizacionais de planejamento e programação da produção - o presente estudo se posicionou de maneira crítica à visão tradicional e funcionalista em que a competência é entendida como sendo constituída por um conjunto de atributos relacionados à conhecimentos, habilidades e atitudes universais. Curiosamente, vale destacar que esse tipo de visão apareceu de maneira recorrente na fala de alguns programadores entrevistados. Conforme mostra Sandberg (2000), a abordagem funcionalista da competência é centrada ou em atributos humanos (worker-oriented), quando se busca quantificar e mensurar capacidades, ou com foco nas atividades (workoriented), que requereriam certos tipos de habilidades (previamente elencáveis) para serem executadas. A abordagem da presente pesquisa, em contrapartida, partiu de uma noção alternativa da competência, a interpretativa, e que está intrinsecamente relacionada às formas em que a competência é experimentada e enriquecida 
cotidianamente pela prática. Entende-se, portanto, que as estruturas e os significados atribuídos à competência mudam conforme mudam as práticas e as maneiras de experimentá-las (DALL'ALBA e SANDBERG, 1996). Assim, o conceito de competência do presente estudo foi abordado segundo a teoria da prática (FELDMAN e ORLIKOWSKI, 2011), mais especificamente a prática das rotinas. Sob essa perspectiva, a competência foi definida pelas concepções que os praticantes da rotina fazem acerca do que é a sua execução competente.

Assim, uma vez que o objetivo do presente estudo foi significar qualitativamente a competência nas rotinas de planejamento e programação, optou-se pelo método fenomenográfico. Segundo Marton (1986), a fenomenografia parte justamente do pressuposto de que todo fenômeno pode ser percebido de diferentes maneiras, em um número limitado de concepções, e que podem ser classificadas qualitativamente. Para Akerlind (2005), o que está na base do método, portanto, é a busca do significado, ou dos significados, de um determinado fenômeno a partir do ponto de vista daqueles que o experimentam. Com isso em mente, a pesquisa foi a campo conversar com programadores de produção para entender como eles definem as rotinas de programação de produção em si e como concebem a competência em sua execução. Ao realizar esse trabalho de campo e ouvir os entrevistados, naturalmente surgiram inúmeras definições e variações sobre o que constitui a competência nas rotinas organizacionais de planejamento e programação da produção. Se considerarmos um grau máximo de detalhe, diríamos que elas variaram conforme variaram as singularidades de cada sujeito consultado. Não obstante, o trabalho de pesquisa foi justamente sistematizar tais concepções, agrupando-as em categorias descritivas e detalhando as dimensões que as diferenciam e explicam.

Especificamente, a abordagem fenomenográfica permitiu explorar entre os programadores de produção as diferentes concepções que eles fazem acerca da competência. Ou seja, a resposta à pergunta de pesquisa do presente estudo está nas três concepções que foram identificadas durante o processo de análise. Tais concepções são as três categorias descritivas que estruturam o espaço de resultados: 1) Alocação de recursos e materiais; 2) Mediação entre diferentes áreas; e 3) Gestão táticoestratégica da operação. 
A primeira categoria descritiva, conforme detalhado na descrição dos resultados, vê a competência na programação de produção estritamente relacionada à "alocação de recursos e materiais". Revelou uma concepção mais tradicional da área de planejamento e programação da produção. Essa abordagem, pode ser considerada como sendo mais funcionalista, porque restringe a noção de competência a uma dimensão exclusivamente operacional. Isto é, as descrições delimitaram a noção de competência à realização da tarefa central da rotina, dando pouco ou nenhum destaque às camadas de relacionamento ou à visão global do sistema. Além disso, mais elementos chamaram atenção nesse grupo. Primeiro, o fato de que o conjunto de relatos que se enquadraram nessa categoria revelou certa resistência a se pensar a rotina organizacional para além de suas rotinas individuais. A competência foi concebida exclusivamente a partir da tarefa principal e do resultado que extraído dela. Em paralelo, notou-se uma atitude que pode ser considerada como majoritariamente passiva em relação as duas principais áreas que afetam e são afetadas pelo trabalho do programador. Em outras palavras, a demanda vem do comercial e deve ser atendida, com pouco espaço para reflexões críticas e negociações. Ao mesmo tempo, as restrições impostas pela equipe de produção delimitam de maneira também restrita as alternativas de programação. A competência para estes programadores, portanto, está em equacionar as informações de entrada do programa (demanda, recursos e materiais) e calcular um sequenciamento que garanta pontualidade de entrega e eficiência produtiva.

A segunda categoria descritiva revelou a concepção de competência mais surpreendente do ponto de vista das expectativas iniciais do estudo, a "mediação entre diferentes áreas". Em tese, o papel histórico da programação é fazer uma intermediação entre as áreas comercial e produtiva. Porém, esta segunda concepção, pelo que se pôde perceber a partir dos relatos, foi muito além desse papel. Em primeiro lugar, ficou claro que não só as áreas comercial e produtiva são mediadas pelos programadores. Eles são percebidos aqui como a intersecção de todas as áreas associadas ao ambiente produtivo. Incluindo, por exemplo, engenharia, qualidade, logística, manutenção, dentre outros. Além disso, seu papel não é apenas gerar um programa que atenda às áreas comercial e produtiva, mas considerar em sua programação os indicadores que regem todas as 
outras áreas. Ou seja, segundo os relatos, o exercício competente das rotinas não está em calcular melhor uma solução, mas em ser efetivamente o elo central da cadeia produtiva, capaz de negociar coletivamente as soluções para a empresa. Por essa percepção, se tornam mais importantes habilidades de relacionamento do que habilidades lógicas. O conhecimento dos indicadores e das restrições de todas as demais áreas envolvidas na rotina se torna tão ou mais importante do que a fidelidade a seus indicadores locais. O programador pôde então ser percebido pela metáfora de um juiz que media a tomada de decisão com base nas argumentações coletivas advogadas pelas demais áreas. Por isso, foi preciso buscar na teoria os tipos de estratégia de negociação existentes. As análises das entrevistas agrupadas nessa categoria descritiva indicam que, nessa segunda categoria descritiva, a competência foi associada ao uso de um tipo estratégia de negociação que a literatura denomina como integrativa (BRETT e THOMPSON, 2016; THOMPSON, WANG e GUNIA, 2010). No caso da programação da produção, seu objetivo é equilibrar os indicadores de cada uma das áreas na construção de uma solução final negociada. Pode se dizer ainda que essa concepção contempla um entendimento amplo da relação de interpendência (DEKEN et al., 2016; CARLILE, 2004), própria à perspectiva prática das rotinas organizacionais (PARMIGIANI e HOWARD-GRENVILLE, 2011).

A concepção consubstanciada na terceira categoria descritiva, por sua vez, confirmou a abordagem estratégica da programação de produção prevista teoricamente (HILL e HILL, 2009 COSTA e JARDIM, 2015; CARVALHO, 2005; SAISSE e WILDING, 1997). Ela foi aqui denominada de "Gestão tático-estratégica da operação". Nessa categoria, o foco da execução competente das rotinas organizacionais de planejamento e programação da produção está em guiar as atividades produtivas e liderar o processo de tomada de decisão, de maneira orientada aos objetivos estratégicos e seus respectivos indicadores globais. Além disso, os relatos indicaram a percepção de que a competência precisa contemplar a capacidade de influenciar e formular as estratégias corporativas. Em relação à dimensão do raciocínio lógico, merece destaque a frequente noção, dentro desta categoria descritiva, de que tal habilidade deveria ser "terceirizada" para sistemas computacionais programados para resolver a dimensão matemática da programação. São as tecnologias denominadas de 
APS (Advanced Planning Systems), amplamente debatidas na literatura tecnológica sobre o tema (NOVELS, 2011; LAFORGE e CRAIGHEAD, 2000). Em linhas gerais, o que os relatos defendem é que esse tipo de tecnologia possibilita aos programadores conhecer mais detalhadamente a realidade da fábrica para avaliar cenários futuros e tomar decisões considerando os impactos de curto e longo prazo. É importante destacar ainda a dimensão explicativa do conhecimento de outras áreas, em que foi possível notar, para além de uma ideia de relacionamento, a frequentemente relatada necessidade de um entendimento profundo sobre a razão de ser e a natureza da função de cada uma das demais áreas, considerando seu papel no desempenho global da operação.

Assim, pode-se dizer que uma contribuição derradeira deste estudo foi demonstrar que a dimensão estratégica começa efetivamente a ser associada às rotinas de planejamento e programação da produção em um número significativo de empresas. Um quarto dos entrevistados, aqueles que compuseram esta terceira categoria descritiva ("gestão tático-operacional da operação"), relataram que atuar ativamente na estratégia da empresa é um dos principais fatores constituintes da competência. Cabe destacar que este um número superou as expectativas iniciais do estudo, mostrando que o caráter estratégico do planejamento e programação da produção aos poucos deixa de ser uma perspectiva majoritariamente acadêmica e passa a ecoar no cotidiano das práticas organizacionais.

Por fim, a partir dos resultados encontrados, nos cabe listar alguns possíveis desdobramentos para futuros estudos ao redor dos temas que foram abordados aqui. No presente estudo, surgiu de maneira marcante a dimensão da negociação dentro das rotinas organizacionais de planejamento e programação da produção. Foi possível fazer uma abordagem inicial e exploratória, especialmente concentrada na dinâmica particular da área em questão que foi objeto do estudo. Nesse sentido, acredita-se que poderia ser promissor avançar nas correlações entre o campo das rotinas organizacionais e o campo das estratégias de negociação, procurando extrapolar para outros tipos de rotinas organizacionais ou buscando generalizações teóricas a respeito de tipos particulares de negociação que eventualmente ocorram no âmbito das relações interdependentes próprias às rotinas organizacionais. 
Em que pese a área de gestão de operações, o foco desse estudo foram as organizações industriais. Futuramente, poderiam ser consideradas outras populações. Um estudo semelhante também poderia ser desenvolvido no sentido de compreender a competência em gestão de operações, porém agora associada a empresas da área de serviços, uma vez que parte dessas empresas não possuem propriamente uma área de programação.

Além disso, outros mecanismos de intermediação entre diferentes atores de uma rotina organizacional também nos parecem apresentar um potencial rico a ser explorado. Além da dimensão de negociação, já citada, apareceram nas entrevistas algumas indicações de que dinâmicas equivalentes podem ser identificadas em temas como comunicação nas rotinas, relações de poder nas rotinas, liderança, o papel dos artefatos nas relações de mediação, e a relação entre comportamento individual e comportamento organizacional dentro das rotinas.

Em relação às rotinas organizacionais de planejamento e programação e seu papel central nas estratégias corporativas, sugere-se também uma investigação longitudinal de tais rotinas. No presente estudo, foram entrevistados apenas programadores de produção. Eles formularam as suas concepções acerca da competência nas rotinas, considerando especialmente as relações de interdependência com outros atores de outras áreas. Um estudo complementar, portanto, poderia ouvir todas as demais áreas e seus respectivos atores envolvidos nas referidas rotinas organizacionais de planejamento e programação. E, desse modo, ampliar a discussão, tanto em relação às rotinas organizacionais de planejamento e programação da produção, quanto em relação à sua dimensão de competência. 
6

\section{Referências bibliográficas}

ADLER, Paul S.; GOLDOFTAS, Barbara; LEVINE, David I. Flexibility versus efficiency? A case study of model changeovers in the Toyota production system. Organization science, v. 10, n. 1, p. 43-68, 1999.

ÅKERLIND, Gerlese S. Variation and commonality in phenomenographic research methods. Higher Education Research \& Development, v. 31, n. 1, p. 115-127, 2012. ARGOTE, Linda; GREVE, Henrich R. A behavioral theory of the firm—40 years and counting: Introduction and impact. Organization Science, v. 18, n. 3, p. 337-349, 2007.

BECKER, Markus C. Organizational routines: a review of the literature. Industrial and corporate change, v. 13, n. 4, p. 643-678, 2004.

BECKER, M.; SALVATORE, Pasquale; ZIRPOLI, Francesco. Applying organizational routines in analyzing organizations: methodological issues and analytical contributions. In: Second Routines Workshop. Sophia-Antipolis, Jan. 2005.

BERTELS, Stephanie; HOWARD-GRENVILLE, Jennifer; PEK, Simon. Cultural molding, shielding, and shoring at oilco: The role of culture in the integration of routines. Organization Science, v. 27, n. 3, p. 573-593, 2016.

BOLANDER, Pernilla; SANDBERG, Jörgen. How employee selection decisions are made in practice. Organization Studies, v. 34, n. 3, p. 285-311, 2013.

BOWDEN, John A. et al. Phenomenography. Phenomenography, p. v, 2000.

BOWDEN, John A. et al. Doing developmental phenomenography. Doing Developmental Phenomenography, p. vi, 2005.

BRADBURY, Hilary; LICHTENSTEIN, Benyamin M. Bergmann. Relationality in organizational research: Exploring the space between. Organization Science, v. 11, n. 5, p. 551-564, 2000.

BRETT, Jeanne; THOMPSON, Leigh. Negotiation. Organizational Behavior and Human Decision Processes, v. 136, p. 68-79, 2016. 
BROWN, Donald E.; MARIN, John A.; SCHERER, William T. A survey of intelligent scheduling systems. In: Intelligent Scheduling Systems. Springer US, 1995. p. 1-40.

BURRELL, Gibson; MORGAN, Gareth. Sociological Paradigms and Organizational Theory. Gower, Aldershot, 1979.

CARLILE, Paul R. Transferring, translating, and transforming: An integrative framework for managing knowledge across boundaries. Organization science, v. 15, n. 5, p. 555-568, 2004.

CARVAlHO, A. R. Gestão Estratégica de Curto Prazo: Origens, Tecnologia e Implantação. 2005. Tese de Doutorado. Dissertação (Mestrado), PUC-Rio, Rio de Janeiro.

CHERMAN, Andrea. Valoração do conhecimento nas organizações: Percepções dos indivíduos e impactos nas práticas organizacionais. 2013. Tese de Doutorado. PUC-Rio.

CHERMAN, Andréa; DA ROCHA-PINTO, Sandra Regina. Valoração do conhecimento nas organizações e sua incorporação nas práticas e rotinas organizacionais. Revista Brasileira de Gestão de Negócios, v. 18, n. 61, p. 416-435, 2016.

COHEN, Michael D. et al. Routines and other recurring action patterns of organizations: contemporary research issues. Industrial and corporate change, v. 5, n. 3, p. 653-698, 1996.

COLLINSON, Simon; WILSON, David C. Inertia in Japanese organizations: Knowledge management routines and failure to innovate. Organization Studies, v. 27 , n. 9, p. 1359-1387, 2006.

CORRÊA, Henrique Luiz. A história da gestão de produção e operações. 2003.

CORREA, Henrique Luiz; PAIVA, Ely Laureano; PRIMO, Marcos André Mendes. A pesquisa em gestão de operações no Brasil: um breve relato de sua evolução. RAE eletrônica, v. 9, n. 2, p. 0-0, 2010.

COSTA, Ricardo; JARDIM, E. G. M. Produção e Serviços: reflexões e conceitos. Atlas, 2015.

COSTA, Ricardo Sarmento. Pontualidade total na produção sob encomenda: conceito, tecnologia e uso da simulação computacional na gestão do chão-de- 
fábrica. 1996. Tese de Doutorado. Universidade Federal do Rio de JaneiroCOPPE/UFRJ.

CRESWELL, John W. Projeto de pesquisa métodos qualitativo, quantitativo e misto. In: Projeto de pesquisa métodos qualitativo, quantitativo e misto. Artmed, 2010.

CYERT, Richard M. et al. A behavioral theory of the firm. Englewood Cliffs, NJ, v. 2, 1963.

DALL'ALBA, Gloria; SANDBERG, Jörgen. Educating for competence in professional practice. Instructional science, v. 24, n. 6, p. 411-437, 1996.

DALL'ALBA, Gloria; SANDBERG, Jörgen. Unveiling professional development: A critical review of stage models. Review of educational research, v. 76, n. 3, p. 383-412, 2006.

DEKEN, Fleur et al. Generating novelty through interdependent routines: A process model of routine work. Organization Science, v. 27, n. 3, p. 659-677, 2016.

DEWEY, John. Human nature and conduct: An introduction to social psychology . New York: H. Holt, 1922.

DODGSON, Mark. Organizational learning: a review of some literatures. Organization studies, v. 14, n. 3, p. 375-394, 1993.

DYER, Jeffrey H.; HATCH, Nile W. Relation-specific capabilities and barriers to knowledge transfers: creating advantage through network relationships. Strategic management journal, v. 27, n. 8, p. 701-719, 2006.

EMIRBAYER, Mustafa. Manifesto for a relational sociology 1. American journal of sociology, v. 103, n. 2, p. 281-317, 1997.

EMIRBAYER, Mustafa; MISCHE, Ann. What is agency? 1. American journal of sociology, v. 103, n. 4, p. 962-1023, 1998.

FELDMAN, Martha S.; ORLIKOWSKI, Wanda J. Theorizing practice and practicing theory. Organization science, v. 22, n. 5, p. 1240-1253, 2011.

FIGUEIRA, E. Compreendendo as Rotinas Organizacionais: Percepção de Consultores em suas Experiências de Campo. 2016. Dissertação (Mestrado), PUCRio, Rio de Janeiro. 
FRENCH, Simon. Sequencing and Scheduling: An Introduction to the Mathematics of the Job-shop, 1982. John Wiley\& Sons, New York.

GARFINKEL, Harold. Studies in ethnomethodology. 1967.

GIDDENS, Anthony. The constitution of society: Outline of the theory of structuration. Univ of California Press, 1984.

GHERADI, S. Organizational knowledge: The texture of workplace learning Organization and strategy. 2006.

GONG, Yan; BAKER, Ted; MINER, Anne. Organizational routines and capabilities in new ventures. 2005 .

GREEN, Pam et al. A rigorous journey into phenomenography: From a naturalistic inquirer standpoint. Doing developmental phenomenography, p. 32, 2005.

HERITAGE, J. Conversation analysis, Garfinkel and ethnomethodology. Polity, 1984. HILL, John; COSTA, Ricardo; JARDIM, Eduardo. Strategic capacity planning and production scheduling in jobbing systems. Integrated Manufacturing Systems, v. 3, n. 3, p. 22-26, 1992.

HILL, Terry; HILL, Alex. Manufacturing strategy: text and cases. Palgrave Macmillan, 2009.

HODGSON, Geoffrey M.; KNUDSEN, Thorbjørn. The complex evolution of a simple traffic convention: the functions and implications of habit. Journal of Economic Behavior \& Organization, v. 54, n. 1, p. 19-47, 2004.

JARDIM, Eduardo; COSTA, Ricardo. Gestão Estratégica de Curto Prazo. Nota técnica Trilha Desenvolvimento de Projetos Ltda., Rio de Janeiro, 2003.

JOHNSTON, Allanah; SANDBERG, Jörgen. Controlling Service Work An ambiguous accomplishment between employees, management and customers. Journal of Consumer Culture, v. 8, n. 3, p. 389-417, 2008.

LAFORGE, R. Lawrence; CRAIGHEAD, Christopher W. Computer-based scheduling in manufacturing firms: Some indicators of successful practice. Production and Inventory Management Journal, v. 41, n. 1, p. 29, 2000. 
LAMB, Peter; SANDBERG, Jörgen; LIESCH, Peter W. Small firm internationalisation unveiled through phenomenography. Journal of International Business Studies, v. 42, n. 5, p. 672-693, 2011.

LATOUR, B. The powers of association. In 1. Law. Power, action and belief: A new sociology of knowledge, 1986.

LAVE, Jean. Cognition in practice: Mind, mathematics and culture in everyday life. Cambridge University Press, 1988.

LEVINTHAL, Daniel; RERUP, Claus. Crossing an apparent chasm: Bridging mindful and less-mindful perspectives on organizational learning. Organization Science, v. 17, n. 4, p. 502-513, 2006.

LEVITT, Barbara; MARCH, James G. Organizational learning. Annual review of sociology, v. 14, n. 1, p. 319-338, 1988.

MACCARTHY, Bart L.; WILSON, John R.; CRAWFORD, S. Human performance in industrial scheduling: a framework for understanding. Human Factors and Ergonomics in Manufacturing \& Service Industries, v. 11, n. 4, p. 299-320, 2001. MARCH, James G.; SIMON, Herbert Alexander. Organizations. 1958.

MARTON, Ference. Phenomenography-describing conceptions of the world around us. Instructional science, v. 10, n. 2, p. 177-200, 1981.

MARTON, Ference. Phenomenography - a research approach to investigating different understandings of reality. Journal of thought, p. 28-49, 1986.

MARTON, Ference; BOOTH, Shirley A. Learning and awareness. Psychology Press, 1997.

MARTON, Ference; PONG, Wing Yan. On the unit of description in phenomenography. Higher education research \& development, v. 24, n. 4, p. 335-348, 2005.

MILAGRES, Rosiléia. Rotinas-uma revisão teórica. Revista Brasileira de Inovação, v. 10, n. 1 jan/jun, p. 161-196, 2011.

MINER, Anne S. Structural evolution through idiosyncratic jobs: The potential for unplanned learning. Organization Science, v. 1, n. 2, p. 195-210, 1990. 
MORGAN, Gareth. Paradigmas, metáforas e resolução de quebra-cabeças na teoria das organizações. RAE-Revista de Administração de Empresas, v. 45, n. 1, p. 58-71, 2005.

PAPKE SHIELDS, Karen; MALHOTRA, Manoj K. Manufacturing managers' perceptions of functional power in manufacturing organizations. International Journal of Operations \& Production Management, v. 28, n. 9, p. 858-874, 2008.

PARMIGIANI, Anne; HOWARD-GRENVILLE, Jennifer. Routines revisited: Exploring the capabilities and practice perspectives. Academy of Management Annals, v. 5, n. 1, p. 413-453, 2011.

PENTLAND, Brian T. et al. Dynamics of organizational routines: A generative model. Journal of Management Studies, v. 49, n. 8, p. 1484-1508, 2012.

PENTLAND, Brian T.; FELDMAN, Martha S. Organizational routines as a unit of analysis. Industrial and corporate change, v. 14, n. 5, p. 793-815, 2005.

PENTLAND, Brian T.; HÆREM, Thorvald. Organizational routines as patterns of action: Implications for organizational behavior. Annu. Rev. Organ. Psychol. Organ. Behav., v. 2, n. 1, p. 465-487, 2015.

PINNINGTON, Ashly H.; SANDBERG, Jörgen. Lawyers' professional careers: increasing women's inclusion in the partnership of law firms. Gender, Work \& Organization, v. 20, n. 6, p. 616-631, 2013.

PINNINGTON, Ashly H.; SANDBERG, Jörgen. Competence regimes in professional service firm internationalization and professional careers. Group \& Organization Management, v. 39, n. 5, p. 561-591, 2014.

QUINN, Gregory; NOVELS, Mike. Analyzing production schedules. IIE Solutions, v. 33, n. 2, p. 38-38, 2001.

RITTER, Mark; SOHAL, Amrik S.; D’NETTO, Brian. Attributes of an outstanding manufacturing manager. International Journal of Manpower, v. 19, n. 3, p. 145-160, 1998.

RERUP, Claus; FELDMAN, Martha S. Routines as a source of change in organizational schemata: The role of trial-and-error learning. Academy of Management Journal, v. 54, n. 3, p. 577-610, 2011. 
SAISSE, Manoel CP; WILDING, Richard D. Short-term strategic management in mass customized markets. Logistics Information Management, v. 10, n. 5, p. 199-207, 1997.

SANDBERG, Jörgen. Understanding human competence at work: an interpretative approach. Academy of management journal, v. 43, n. 1, p. 9-25, 2000.

SANDBERG, Jörgen; DALL'ALBA, Gloria. Returning to practice anew: A life-world perspective. Organization Studies, v. 30, n. 12, p. 1349-1368, 2009.

SANDBERG, Jörgen; TSOUKAS, Haridimos. Grasping the logic of practice: Theorizing through practical rationality. Academy of Management Review, v. 36, n. 2, p. 338-360, 2011.

SCHEMBRI, Sharon; SANDBERG, Jörgen. The experiential meaning of service quality. Marketing Theory, v. 11, n. 2, p. 165-186, 2011.

SIMON, Herbert A. How big is a chunk?. Science, v. 183, n. 4124, p. 482-488, 1974. SZULANSKI, Gabriel. Exploring internal stickiness: Impediments to the transfer of best practice within the firm. Strategic management journal, v. 17, n. S2, p. 27-43, 1996.

TAYLOR, Charles. To follow a rule. Bourdieu: critical perspectives, v. 6, p. 45-60, 1993

THOMAS E. VOLLMANN; WILLIAM L.. BERRY; WHYBARK, D. Clay. Manufacturing planning and control systems. Irwin/McGraw-Hill, 1997.

THOMPSON, Leigh L.; WANG, Jiunwen; GUNIA, Brian C. Negotiation. Annual review of psychology, v. 61, p. 491-515, 2010.

TRIGWELL, Keith. A phenomenographic interview on phenomenography. Phenomenography, p. 62-82, 2000.

TURNER, Scott F.; FERN, Michael J. Examining the stability and variability of routine performances: the effects of experience and context change. Journal of Management Studies, v. 49, n. 8, p. 1407-1434, 2012.

TURNER, Scott F.; RINDOVA, Violina. A balancing act: How organizations pursue consistency in routine functioning in the face of ongoing change. Organization Science, v. 23, n. 1, p. 24-46, 2012. 
VERGARA, Sylvia Constant et al. Paradigma interpretacionista: a busca da superação do objetivismo funcionalista nos anos 1980 e 1990. Revista de Administração de Empresas, v. 45, n. 4, p. 66-72, 2005.

WINTER, Sidney G. The satisficing principle in capability learning. Strategic management journal, p. 981-996, 2000.

WINTER, Sidney G.; NELSON, Richard R. An evolutionary theory of economic change. 1982.

ZIMMERMAN, Don H. The practicalities of rule use. Understanding everyday life, p. 221-238, 1970. 


\section{Apêndice I. Roteiro semiestruturado}

Formulação do Roteiro de Entrevistas

Apresentação

Olá, você me autoriza a gravar nossa conversa? Esse procedimento facilitará a retomada do conteúdo posteriormente. Estou entrevistando programadores para minha investigação para compreender as competências na rotina (atividades) de programação da produção. Para tanto, a identidade do entrevistado não será revelada e o seu relato utilizado para fins acadêmicos. Fique à vontade para abordar o que considerar relevante acerca do que for questionado.

\section{Questões introdutórias}

1.1. Para contextualizar, você poderia me falar qual é o porte da empresa, o setor de atuação, seu tempo de experiência profissional e sua a formação acadêmica.

\section{Perguntas centrais}

2.1. O que significa programação da produção para você?

2.2. O que é para você um programador de produção competente?

\section{Questões de desenvolvimento das experiências}

3.1. Quais dificuldades você encontra para programar a produção? Pode me descrever uma experiência nesse aspecto?

3.2. Quais facilidades você encontra para programar a produção? Pode me descrever uma experiência nesse aspecto?

3.3. De acordo com sua percepção, quando ocorre uma experiência malsucedida nas rotinas de programação da produção?

3.4. De acordo com sua percepção, quando ocorre uma experiência bem-sucedida nas rotinas de programação da produção?

\section{Perguntas acessórias}



a. Você poderia me dar um exemplo?
b. Você poderia me explicar (isso) melhor?
c. Como você faz/fez (isso)?
d. Por que (isso) ocorreu?
e. Como você superou (isso)?
f. Como (isso) te ajudou?
g. Qual o significado (disso) para você?
h. Para quem?
i. Por que?

Encerramento

Agradecimentos 


\section{Apêndice II. Lista de termos específicos}

\begin{tabular}{|c|c|c|}
\hline 1 & PCP & Planejamento de Controle da Produção. \\
\hline 2 & PPCP & Planejamento, Programação e Controle da Produção. \\
\hline 3 & Cronoanálise & $\begin{array}{l}\text { Técnica de medição dos tempos necessários para a } \\
\text { realização de cada processo. }\end{array}$ \\
\hline 4 & Lean & $\begin{array}{l}\text { Manufatura Enxuta, filosofia de gestão da produção } \\
\text { inspirada no Sistema Toyota de Produção. }\end{array}$ \\
\hline 5 & Gargalo & $\begin{array}{l}\text { Ponto de um sistema produtivo que limita sua } \\
\text { produtividade geralmente por possuir uma } \\
\text { capacidade menor. }\end{array}$ \\
\hline 6 & MRP & $\begin{array}{l}\text { (Material Resource Planning). Técnica geralmente } \\
\text { apoiada por software que se refere ao planejamento } \\
\text { de materiais e recursos para produção. }\end{array}$ \\
\hline 7 & APS & $\begin{array}{l}\text { (Advanced Planning and Scheduling). Refere-se aos } \\
\text { sftwares de planejamento avançado de produção. }\end{array}$ \\
\hline 8 & $\begin{array}{l}\text { Capacidade } \\
\text { Finita }\end{array}$ & $\begin{array}{l}\text { Sistemas APS que consideram todas as restrições de } \\
\text { capacidade ao fazer o planejamento avançado de } \\
\text { produção. }\end{array}$ \\
\hline 9 & Simulador & $\begin{array}{l}\text { Um tipo de APS com capacidade finita baseado em } \\
\text { uma lógica de criação e avaliação de cenários com } \\
\text { base em tentativa e erro. }\end{array}$ \\
\hline 10 & $\begin{array}{l}\text { Estudo da } \\
\text { capacidade }\end{array}$ & $\begin{array}{l}\text { Avaliação da capacidade produtiva de cada etapa do } \\
\text { processo industrial. }\end{array}$ \\
\hline 11 & $\begin{array}{l}\text { Balanceamento } \\
\text { de capacidade }\end{array}$ & $\begin{array}{l}\text { Regulação dos processos para que todos tenham } \\
\text { uma capacidade nivelada. }\end{array}$ \\
\hline
\end{tabular}

